Hat ein Satz mehrere Subjecte oder mehrere Prädicate, so ist es das Regelmälsige und Gewöhnliche, dafs die zusammengehörenden Satztheile zusammentreten z. B. Gen. X 2. 3. XIIl 13. Es finden sich jedoch auch Fälle, wo mehrere Subjecte das Prädicat einschliefsen oder umgekehrt mehrere Prädicate das Subject, besonders häufig in der Poesie : z. B. Amos V 20. Prov. VIII 18. Psalm CXLVII 5. 6.

In einem Falle giebt es keine Ausnahme von der regelmälsigen Stellung der Worte im Nominalsatz - im sogenannten Umstands- oder Zustandssatz, selbst nicht in der Poesie z. B. Gen. XIX 1. Richt. IV 5. Koh. II 3.

\title{
Die Composition des Buches Jona.
}

\section{Von W. Böhme.}

Ueber der viel ventilirten Frage nach dem historischen Charakter, dem Zweck und der Bedeutung des Buches Jona für die israelitische Religionsgeschichte wie für die christliche Kirche ${ }^{1}$ ) hat man allerdings die Untersuchung des Textes nicht vernachlässigt, aber dieselbe doch nicht in einer befriedigenden Weise geführt. Manche Bedenken, die sich mir bei der Betrachtung der Ueberlieferung erhoben haben, finde ich bis jetzt nicht berührt, hinsichtlich

1) Die den Jona betreffenden Worte Jesu Matth. 12, 39-41. Luc. 11, 29 f. 32 sind meines Erachtens oiner erst nach dem Evangelium Marci und theilweise mit Rücksicht auf dasselbe entstandenen, von Matth. und Luc. benutzten Schrift entnommen, deren Inhalt, Wortlaut und geschichtlicher Werth (bauptsächlich der letztere) noch nicht festgestellt ist, in vielen Einzelheiten mit Sicherheit auch wohl nicht festgestellt werden kann. Uebrigens ist weder in Mt. 12 (Mt. 16, 4) noch in Lc. 11 der Text der Quelle unverändert erbalten. Näheres im Osterprogramm des Gymnasiums zu Stolp 1887. 
anderer hat sich, soviel ich sehe, die neuere Kritik nach dem Vorgange von Gelehrten wie Hitzig an der Vermuthung genügen lassen, dafs ein Schriftsteller, dessen „ganze Erzählung wunder- und märchenhaft lautet ${ }^{\star}$, der in dem Bericht von der Bekehrung der Nineviten eine „psychologisch unwahrscheinliche Behauptung“ vorträgt, der überdies „alle genaueren Umstände verschweigt, welche seinen Flug nach dem unhistorischen Ziele nur hemmen würden" - dafs ein solcher Schriftsteller auch wohl hier und da eine „Verkehrtheit" begehen konnte wie die, dafs nach ihm Jona in 4,5 die Stadt verläIst, um zu erfahren, was er nach 4, $1 \mathrm{ff}$. schon wissen mufs. So berechtigt nun auch viele Vorwürfe sind, welche man gegen die Darstellung in unserem Buche vorgebracht hat, so wenig darf man sie auf das Haupt eines einzigen Autors häufen. Unser Text nämlich entstammt (was man bei dem geringen Umfang der Schrift nicht erwarten sollte) nicht einer einheitlichen Conception, sondern ist das Resultat mehrerer Bearbeitungen, die sich nicht alle auf das ganze Buch erstreckten und besonders aus diesem Grunde bisher nicht erkannt worden sind. Indem ich den Beweis für die Richtigkeit dieser meiner Ansicht antrete, gestatte ich mir zugleich diejenigen Verse zu behandeln, welche nur durch eine unbedeutende Interpolation, eine irrige Lesart oder Punctation entstellt zu sein scheinen.

In Cap. 1 bezweifle ich schon die Integrität von V.3. Da die Schiffer nicht ebenfalls vor Jahve fliehen, so fällt der Schluls des Verses sehr auf; da überdies בוא מלפני (oder הלך) nirgends vorkommt, so glaube ich, dafs wir die Worte מלפני ידוה (oder Glossator) verdanken. Weiter befremdet nicht nur die dreimalige Setzung des Ausdrucks „nach Tarsis“, sondern auch der Umstand, dals die von den andern Wendungen abweichende Form תרשיש in der Mitte steht, so dafs wir, wenn der Text hier unbeschädigt wäre, ein merkwürdiges Schwanken des 
Schriftstellers annehmen mufsten. Nun ist die Angabe "nach T'Tarsis" sowohl am Ende des Verses wie in der Mitte desselben nicht wohl $\mathrm{zu}$ entbehren; dagegen fragt es sich, ob dem Propheten, der da gewillt war sich der Ausfuhrung des göttlichen Befehles zu entziehen, gleich anfangs das Ziel seiner Reise uber das Meer feststand; vielleicht ist erst, als er im Hafen von Joppe ein für Tarsis bestimmtes Schiff vorfand, der Entschlufs in ihm gereift, in jenes fernste aller Länder zu fahren. (לברח תרשישה) treffen wir freilich auch 4, 2 an, aber dort, wie sich zeigen wird, nicht von der gleichen Hand, welche die älteste Darstellung in unserm Capitel verfafste.) Demnach dürfte es angemessen sein, das erste תרשישה entweder zu entfernen oder als den Zusatz eines Späteren anzusehn, der die Ueberlieferung einer Ergänzung bedürftig hielt; ob man aber dem ursprünglichen Erzähler einen einmaligen Wechsel der Formen mit und ohne $\pi_{T_{1}}$ zutrauen darf oder die eine derselben nach der andern corrigiren muls, das zu entscheiden überlasse ich dem Urtheil des Lesers. - 1, 4 ist das Sätzchen ויהי סער גרול בים, welches seinem Inhalt nach nichts Neues bietet, schwerlich ariginal, zumal wegen der Wiederholung von לור, das man hinter רוח ungern missen möchte ${ }^{1}$ ). Ich vermuthe, dafs der erste Concipient unserer Geschichte erst durch den Ausdruck רוֹלך וֹסער 1, 11 auf סער גרול V. 12 geführt worden ist, welche Bezeichnung dann ein Anderer bereits in 4 verwandte. - In 5 b erregt das aramäisch-arabische ספינה statt des in 3.4 .5 a gebrauohten gewöhnlichen אניה unsere Verwunderung. Ferner begegnen wir hier einem רב חבל, während sonst im Cap. und speciell in den Verhandlungen mit Jona nur ndie

1) In 1 Kön. 19, 11 zeigt die Differenz im Genus von dem der folgenden Attribute, sowie der Mangel an naheren Bestimmungen bei den mit חר parallelen Substantiven, dafs die Worte von pint bis a oingesohaben sind. 
Männer" (V. 5 dafür הים auftreten. Man könnte die Einführung des Capitäns (wenn dies die richtige Uebersetzung des Titels ist) darin begründet erachten, dals die Schiffer vollauf mit der Rettung des Fahrzeugs zu thun haben und dafs ein einzelner Mann, hier der wohl als weniger beschäftigt gedachte Befehlshaber, genügte, um eine Frage und Ermahnung an den Propheten zu richten. Allein weshalb hat der Erzähler sich dieser so geeigneten Person in der Folge nicht mehr bedient, z. B. bei dem Vorschlag zu loosen, bei der Erkundigung nach Jonas Herkunft, Vorhaben (Verschuldung)? Diese Erwägungen waren es, welche in mir den, weiterhin sich bestätigenden Verdacht erweckten, 5 b und 6 möchten von einem Ergänzer des Buches herrühren. Derselbe war der Meinung, man werde den Jona, dessen Beten er nicht erwähnt fand und bei der Stellung des Propheten zu Jahve auch" nicht erwähnt finden konnte, zu gleichem Thun wenigstens aufgefordert haben; überdies beabsichtigte er vielleicht dadurch, dafs er ihn in einen tiefen Schlaf fallen liefs, den Lesern einen augenfälligen Beweis von der Sorglosigkeit zu geben, welcher der Prophet sich überliefs, seitdem er sich aufserhalb des Bereiches Jahves wähnte. Hitzig's Auslegung zu 1, 5 : „beim Entstehen des Sturmes sonderte er sich in seinem bösen Gewissen (V. 12) von den Uebrigen, warf sich muthlos hin und schlief abgespannt und sich selbst aufgebend ein " ist verfehlt. Vielmehr vergleicht sich die Situation in diesen Versen mit der in Marc. 4, $35 \mathrm{ff}$. geschilderten. Jesus wie Jona schlafen vor dem Sturm ein (die Tempora in Jon. 1, $5 \mathrm{~b}$ sind als Plusquamperfecte

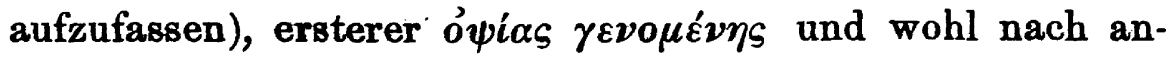
gestrengter Tagesarbeit, letzterer, weil er hier von Jahve nichts Böses fürchtet - wenn dem Erweiterer des Textes nicht die ihm nach 4, 3 wohlbekannte Stelle 1 Kön. 19, 4 ff. vorschwebte, wo es von Elia heifst וישכב וישו und der den Propheten anrührende Engel spricht קום אככול Bei. Bei 
dem alten Erzähler dagegen werden die Schiffer dadurch, dafs ihr Rufen zu den Göttern und der Versuch, durch Entlastung des Fahrzeugs sich selbst zu helfen, sie von der Gefahr des Unterganges nicht befreit hat, zu dem Glauben gebracht, dals ein unbekanntes Verbrechen einer der auf dem Schiffe befindlichen Personen den Zorn einer Gottheit heraufbeschworen habe, und erst das Loos lenkt ihre Aufmerksamkeit auf den Propheten, um den sie sich bis dahin nicht gekümmert haben, und den sich der Schriftsteller wohl theilnahmlos oder trotzig in das Unwetter schauend dachte, da Jahve ihm persönlich nichts anhaben werde; vorausgesetzt, dafs der Autor sich die Frage nach dem Verhalten des Jona während des Sturmes überhaupt vorlegte. Die Verbindung מהזילך נרדָם nicht analog der Redeweise in den von Hitzig citirten Stellen Ps. 50, 16. Jer. 2, 18 (an beiden Orten folgt ein $ל$ nach מה-אר) ist gleichwohl schwerlich von der Art, dafs man eine Corruption das Textes annehmen mülste, sondern als Kürze in lebhafter Rede, möglicherweise auch als Eigenthümlichkeit eines jüngeren Sprachgebrauchs zu erklären; correct würde

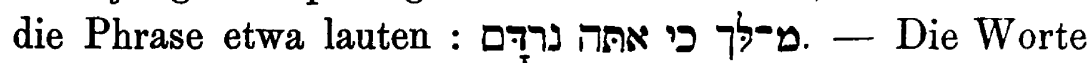
in באישר למי הרעה הזאה לנו, noch nicht zur Zeit der LXX vorhanden, werden mit Recht von Grimm und Hitzig als ein verirrtes Glossem zu der ähnlichen Wendung in 7 angesehen, deren Ausdruck בשלטי, bei dem Mangel der Punctation in der alten Schrift ein vieldeutiges Wort, von einem Leser interpretirt wurde. In demselben Verse ist mir aber auch der Passus מד ארצך ואי מזה עם אתה als eine spätere Einfügung verdächtig. Schon die Frage מאין תבוא, die keiner ausführlichen Erläuterung bedurfte, konnte den Fremdling veranlassen, Land und Leute, von denen er herstamme, anzugeben. Aufserdem folgt an sämmtlichen

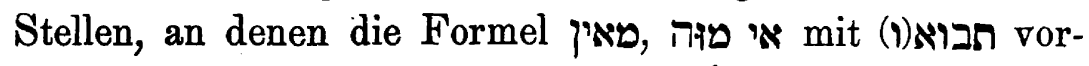
kommt, Richt. 17, 9. 19, 17 (vorher אנה תלך) 2 Sam. 1, 3. Hiob 1, 7. 2, 2. Jos. 9, 8 (vorher מי אפם) 2 Kön. 20, 14 


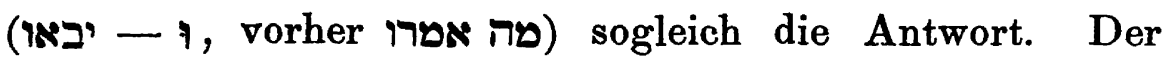
Urheber des Zusatzes in unserm Verse fand die Erwiderung des Propheten nicht entsprechend der Frage ,woher kommst du ?", sondern in אִבְרִ אנכי das Volk genannt, dem Jona angehörte. So ergänzte er die Frage, indem er sich in der ersten Wendung mit מה מה an seine Vorlage anlehnte

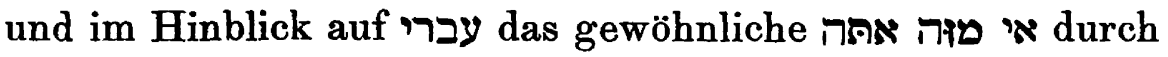
(ארץ (nach erweiterte. Ueber die in der Frage erwähnte מלאכה giebt Jona in 9 keine Auskunft; dagegen hören wir in 10 zur Begründung des vorwurfsvollen Ausrufs מה-צאת עשית, dafs der Prophet der Schiffsmannschaft seine Flucht vor Jahve mitgetheilt hatte, wobei er auch seines Berufes und des göttlichen Auftrags gedenken mufste. Warn nun eine Mittheilung hierüber stattgefunden hatte, wird nicht gesagt; ohne directe Aufforderung wird Jona sie nicht gemacht haben, eine solche wird aber erst V. 9 an ihn gerichtet. Nichts wäre natürlicher gewesen als dafs der Schriftsteller den Propheten über seine Thätigkeit und über die Veranlassung zu seiner Reise sich in einer Fortsetzung der Rede v. 9 aussprechen liefs. Nun treffen wir aber eine hierauf bezügliche Aeufserung im überlieferten Text nicht an. Da liegt uns denn der Gedanke nahe, dafs dieselbe in 9 von dem Verfasser dieses Verses ursprünglich nicht mitgetheilt, dafür aber von ebendemselben ein Ersatz in $10 \mathrm{~b}$ gegeben wurde. Indessen die Wendung in dem Bekenntnifs des Jona 12 b (formulirt nach 7 בשלמי וג) ᄁich weifs, dafs um meinetwillen dieser gewaltige Sturm entstanden ist" lautet keineswegs so, als hätten die Heiden von Jonas Vergehen bisher etwas erfahren. Kannten sie dasselbe schon, so war jene Begründung zu שָ ư u. s. w. entweder ganz fortzulassen oder mit einer andern des Sinnes $\eta^{i h r}$ wifst, ich habe euch gesagt ${ }^{\star}$ zu vertauschen. Dals der Prophet Böses gethan hat, schliefsen die Schiffer aus der Entscheidung des Looses, welche für sie die Bedeutung eines Gottesurtheils hat; Jona bestätigt nur, in- 
dem er seine Sünde zu kennen gesteht, ihre Ansicht, damit sie sich nicht scheuen ihn zu opfern. Man ist also wohl zu der Folgerung berechtigt, dafs in der originalen Darstellung die Schiffer nach dem Schuldbekenntnifs des Propheten von näheren Erkundigungen nach dem Beruf des Fremden, dem Zweck seiner Reise, der Art seiner Schuld Abstand nahmen, nachdem sie - worauf es ihnen in ihrer Lage vor allem ankam - die Person des Schuldigen ermittelt, den Urheber des Sturmes (der ja nur ein Gott sein konnte 1, 7, in unserm Fall Jahve war 1, 9), zuletzt auch noch das Mittel ihrer Rettung kennen gelernt haben. Daher brauchen wir das Fehlen einen Angabe über die טלאכה des Propheten nicht so zu erklären, dals der ursprüngliche Verfasser dem Propheten die Beschämung ersparen wollte, über sein Vergehen zu reden, oder dafs nach ihm Jona bei diesen Heiden kein Verständnifs für die Schwere seiner Verschuldung voraussetzen konnte, oder auch so; dafs die Rede des Propheten nach der Nennung Jahves durch die entsetzten Zuhörer unterbrochen ward. Sollte der Darsteller der Urschrift eine Mittheilung über die טלאכה des Propheten nur aus Versehen unterlassen haben, so mufs man annehmen, dafs er, auch wenn er später seinen Irrthum wahrnahm, es doch nicht für nöthig hielt, denselben zu verbessern; vielleicht selbst aus dem Grunde, weil ja der Leser mit Jonas ' kannt war. Das wäre allerdings, zumal nachdem der Autor die Frage מה־עלאכתך einmal geschrieben hatte, nicht zu billigen, und ein Bearbeiter des Buches hatte insofern Recht, wenn er das von jenem Versäumte nachzuholen bemüht war; nur ist das von ihm nicht in geschickter Weise geschehen. Zu der Vermuthung, dafs מה-שלאכחר ein jüngerer Einsatz sei, haben wir keinen Grund (zur Stellung der Worte עה אמרו (נ' ומאין יבאו, ebenso wenig aber zu der Hypothese, dafs eine im ältesten Bericht gegebene Erklärung der טל מל durch 
die Schuld eines Abschreibers ausgefallen sein dürfte. Was nun den Wortlaut des Originals betrifft, so wird derselbe kaum folgender gewesen sein : „da fürchteten sich die Männer sehr und sprachen zu ihm : warum hast du das gethan? und sie sprachen $\mathrm{zu}$ ihm : was sollen wir dir thun?" sondern schon der Ausruf מדיהאח עשית gehört dem Ergänzer an und ist in der Form wohl mit Beziehung auf פ.11 gebildet, welches gleichfalls nach einem

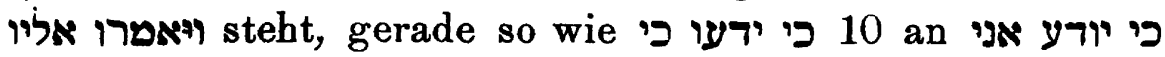
12 erinnert. Sonach halte ich alles, was wir in unserm Text zwischen מרו אמרו אליו V. 10 und 11 lesen, für einen Einschub und מדזיאת עשית schon mit Rücksicht auf die Begründung in $10 \mathrm{~b}$ geschrieben. - Innerhalb der Verse 11-13 bin ich in Zweifel über die Ursprünglichkeit des Satzes וישחק הים מעליכם in 12, der eine Phrase. aus 11 unnöthiger Weise noch einmal bringt, während die Wiederholung von $11 \mathrm{~b}$ in $13 \mathrm{~b}$, mit dem von der gleichen Anסيער עליהם 11 a ausgehenden וישתק מעלינו doch wohl durch den Zusammenhang sich rechtfertigen läfst. - Nach V. 13 macht die Schiffsmannschaft noch einen letzten Versuch das Land zu gewinnen (חת term.

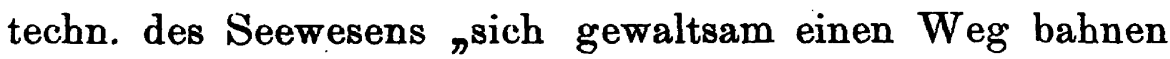
durch die Fluth" ${ }^{*}$ gl. perrumpere?). Offenbar wünscht sie den Propheten, der ihr nichts zu Leide gethan hat, nicht dem sicheren Tod preiszugeben. Ein anderes Motiv ihrer Handlungsweise enthüllt uns zwar V. 14; aber die Bitte der Schiffer אל-תמן עלינו דם נקיאה, wonach sie den Jona für unschuldig halten, steht im Gegensatz zu der eigenen Aeufserung des Propheten בשלי הםער und zu dem Verfahren eben des Gottes, den sie anrufen und der seinen Gesandten deutlich genug schuldig erklärt hat. Unzulässig ist die obige Wendung im Munde der Seeleute auch dann, wenn man meint, dáfs sie für ihre Person das Vergehen des Jona nicht als todeswürdig auffassen, weil sie „keinen rechten Begriff dafür haben" (Hitzig). Mufsten sie ihre 
etwa abweichende Ansicht über des Propheten Schuld nicht dem Urtheil Jahves unterordnen (vor dem sie sich doch schon nach V. 10 fürchten), insbesondere dann, wenn sie sich an ihn mit der Bitte um Erhaltung ihres Lebens wandten? Gesetzt nun auch, man wollte jene Phrase als Interpolation ausscheiden, wozu man jedoch nicht im Geringsten gezwungen ist, so bliebe noch immer das befremdliche אל-נא נאברה der Schiffer. Wie seltsam von ihnen, Jahve um Errettung aus ihrer schlimmen Lage anzuflehn, da die Fortdauer derselben ihre Schuld ist, und da sie, genau genommen, schon durch ihr Zögern in der Vollstreckung der Strafe an Jona (der da weifs, dals das Unwetter um seinetwillen ausgebrochen ist) sich höchst straffällig machen! Nach alledem bin ich überzeugt, dafs hier ein Bearbeiter der älteren Schrift den wahren Beweggrund, der die Schiffer bei ihrem Thun leitete, nämlich eine leicht begreifliche Regung des Mitleids mit dem Propheten, verkannt und auch wohl beabsichtigt hat ,dem Jahvediener den gebührenden Respect ... erzeigen zu lassen" (HitzigSteiner S. 174). - Ob schon den ersten Erzähler der Eindruck interessirte, den die durch Jonas Versinken plötzlich herbeigeführte Beruhigung des Meeres, den überhaupt das merkwürdige Walten Jahves im Leben des Propheten auf die heidnischen Schiffer ausüben mufste, ist mir sehr fraglich; glaublicher scheint mir, dafs ein Erweiterer der kurzen Vorlage, nicht zufrieden damit, dafs die Seeleute nach V. 10 sich vor Jahve schon fürchten, nach den zuletzt beschriebenen Vorgängen eine Angabe über ihre völlige Bekehrung und auch die Mittheilung von Beweisen ihrer Frömmigkeit (ähnlich wie sie später die Nineviten gaben) für unumgänglich nothwendig halten mochte.

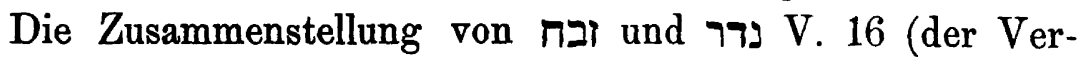
fasser begnügt sich also nicht mit dem letzteren) stimmt auffällig mit der Formel am Schlufs des Gebets 2, 10; der erste Theil des Verses aber ist nur eine, durch das wahr- 
scheinlich ächte אתחיהוה vermehrte Wiederholung des Anfangs von 10.

חששבה Hinsichtlich der Punctation wird man sich das Piel 1, 4 (nicht Kal) wohl gefallen lassen; unmöglich aber giebt im massoretischen Text des A. T. die Aussprache wieder, welche dieses Wort in alter Zeit auf palästinensischem Boden gehabt hat. Nach dem im Assyrischen gewöhnlichen Ninua darf man für das Hebräische, in welchem

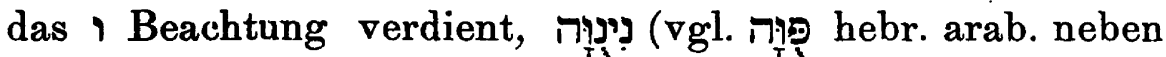

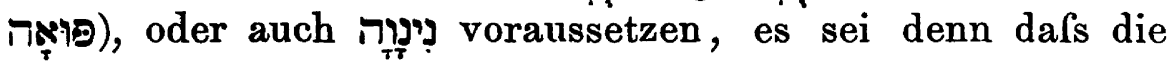
Israeliten, um das Fremdwort in ihrer Sprache sich zu deuten, den letzten Theil desselben in נָּ umänderten. Vielleicht hat erst die weitere Corruption des $\mathbf{N}$. pr. durch

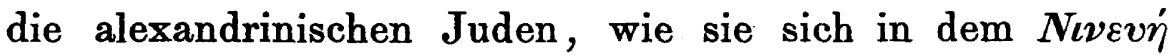
der LXX darstellt, die jetzige Vocalisation desselben veranlafst ${ }^{1}$ ).

Dafs das Gebet in Cap. 2 nicht vom ältesten Darsteller verfafst ist, haben schon mehrere Forscher erkannt. Von Wichtigkeit ist die in den einleitenden Worten V. 2

1) In der überlieferten Punctation von Ezech. 29, 10 mit. Targ. JDMich. das griechische $\Sigma v \eta \dot{v} \eta$ und will daher mit Mich. nach dem Koptischen und den Hieroglyphen ơ oder סִוֹנָד (so auch Cornill) lesen; jedenfalls wird q und I den A-laut gehabt haben. Ueberhaupt unterliegt die Vocalisation der nichtsemitischen Eigennamen im M. T. häufig grofsen Bedenken. Hier nur noch ein Beispiel. Bertheau äufsert in Bezug auf 17 Esth. 1, 1 (8, 9), man habe sich bei den Vocalen dieses Wortes wohl nach der Analogie der ähnlichen hebräischen Wörter 1 aber das דור הoblieder, dessen Vocale man nahm, trotzdem durch das, wie ich glaube, richtig überlieferte Dagesch die Setzung eines O sich nicht empfahl. Zn punctiren ist הדיר, nach dem Sapta Sindhavas des altesten Sanskrit, dem Hapta Hendu des Zend, dem syrischen Hendu and dem arabischen Hind. Das 3 fiel wohl erst beim Uebergange in das Hebräische aus, wie z. B. in טִנִךרה (assyrisch mandatta, maddattu u. ä., im Hebräischen zur Zeit

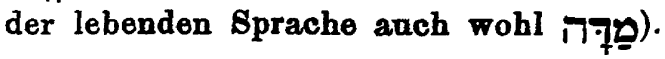


vom biblischen Sprachgebrauch sich entfernende Verwendung von רגה als nomen unitatis (denn wie überall, so ist auch in כל־דגה Deut. 4, 18, Ez. 29, 4 f. רגה als Collectivum gedacht; anders urtheilt über die erstgenannte Stelle noch Gesen. Lexik. 9. Aufl.), während in derselben Bedeutung 2,1 a. $1 \mathrm{~b}$ und wieder in 2,11, der Sitte des A. T. gemäls, 27 geschrieben wird. Von der Verbindung 2a dürfen wir schon hier vermuthen, dafs sie in Beziehung steht zu יהוה אלה 7 b. In der Erzählung ist sie noch weniger angemessen als im Liede, da Jona zu dem Gotte fleht, dem er bis dahin ungehorsam war; sollte aber das Suffix in אלהיו nur auf die Verehrung Jahves durch Jona als einen Angehörigen Israels hinweisen (vgl. 1, 9), so wäre die Betonung Jahves als des Nationalgottes hier, wo es sich nicht um den Gegensatz zum heidnischen Götzenwesen handelt, kaum in der Ordnung. Spricht man nun das Lied und die Einfügung desselben (letzteres um הרגה willen) dem originalen Erzähler ab, so wird sich einem leicht der Gedanke aufdrängen, ein Ergänzer habe wenigstens den Satz ויתפלל יונה אל-יהוה bereits vorgefunden und daraus Veranlassung genommen, den Psalm hier einzusetzen. Jedoch ist das keineswegs nöthig; vielmehr lassen sich alle das Gebet einleitenden Worte ebenso gut wie dieses selbst entbehren. „Jona blieb im Leibe des Fisches drei Tage und Nächte; da gebot Jahve dem Fisch" u. s. w. ist ein lückenloser Bericht, nach meiner Meinung der ursprüngliche. Ihm znfolge verdankt der Prophet nur dem freiwilligen Erbarmen Jahves (der ihn allerdings so wenig im Bauche des Thieres wie in den Wogen des Meeres durfte umkommen lassen, wenn er gerade ihn zum Bufsprediger in Nineve auserkoren hatte) seine Erlösung aus der dunkeln Behausung; durch die Einschiebung des Liedes aber gewinnt es jetzt den Anschein, als ob Jona durch sein demüthiges und glaubensvolles Gebet das Wohlwollen "seines Gottes" sich wiedererworben habe. Das Motiv 
zum Einsatz des Psalms ward ohne Zweifel die scheinbare Aehnlichkeit der in demselben vorausgesetzten Situation des Sängers mit der des Jona, besonders in שפטן שמול בטעי הקג $1 \mathrm{~b}$; auch mag diese Aehnlichkeit für einen Bearbeiter des Buches der Grund gewesen sein, das Gedicht möglichst nahe an die Wendung במעי הקג heranzurücken; eine passendere Stelle hätte es als Danklied für eine Errettung sicherlich hinter V. 11 gefunden. Eine Interpolation er. blicke ich in 9, dessen erster Theil die Randbemerkung eines Lesers enthält, der sich an Ps. 31, 7 שנאת' (שמרים) הבלי-שוא erinnerte. Wie er hierauf verfiel, ist unklar, doch zu beachten, dafs Ps. 31, 23 in Jon. 2, 5 a benutzt ist. An grofser Dunkelheit leidet $9 \mathrm{~b}$; השמרים statt des singulären טשמרים verlangt de Wette-Schrader Einl. in d. A. T., wohl mit Recht, da der Urheber der Interpolation kaum beim Citiren sich versah oder absichtlich abwich. $\mathrm{Ob}$ man nun an unserer Stelle den Ausfall eines שנאת' nach Ps. 31, 7 annehmen will oder nicht, unbegründet ist in diesem psalmartigen Gedicht, welches sich sonst nur mit Jahve und dem durch ihn Geretteten beschäftigt, ein Seitenblick auf das Treiben Anderer und die Verurtheilung desselben durch den Dichter (auch nach de Wette-Schrader a. a. O. pafst V. 9 gar. nicht auf Jona). Dagegen schlofs sich in der ursprünglichen Fassung an das, was Jahve an dem Bedrängten gethan, vortrefflich die Angabe dessen, was der aus der Noth Befreite Gott zum Dank darbringen will, und so trat ואני in eine Art Parallelismus zu Jahve, nicht, wie es jetzt den Eindruck macht, in Contrast zu dessen Verächtern. - Die in $5 \mathrm{~b}$ nicht zu missende Phrase אל-היכל קרשך wurde vermuthlich von da an den Schlufs von 8 herübergenommen; hier erscheint sie unnöthig; da der Ort, von welchem aus Jahve die Gebete erhört, wahrscheinlich der Himmel gedacht ist. - Eine Erweiterung 
des älteren Textes tritt uns auch in V. 6 und 7 entgegen. Dafs der Sänger, nachdem er in 4 die zur Erklärung des Ausdrucks שבטן שמול dienende Schilderung seiner Lage und in 5 die seiner Empfindungen gegeben, sich von neuem einer Beschreibung seines Zustandes zugewendet habe, wie sie uns in $6 \mathrm{f}$. vorliegt, will mir nicht einleuchten. Ferner ist nicht nur ירוה אלה ירויה, sondern auch ein einfaches יהוה als Anrede dem Gedichte fremd, in dessen erzählenden Partieen auf den Gottesnamen des ersten Versgliedes (in $10 \mathrm{~b}$ steht derselbe erst am Schlufs) in der zweiten Hälfte des Verses das Verbum in der zweiten Person zu folgen pflegt (vgl. $3 \mathrm{~b}$ und $8 \mathrm{~b}$ mit $3 \mathrm{a}$ und 8a; eine Ausnahme יעניע 3a). (Den Halbvers $7 \mathrm{~b}$, der sich über die Rettung bestimmter ausdrückt als $3 \mathrm{a} .3 \mathrm{~b}$. $8 \mathrm{~b}$, umzustellen, etwa hinter $8 \mathrm{~b}$, haben wir keinen Grund, $\mathrm{da} 8 \mathrm{~b}$ zum Hinweis auf dieselbe ebenso genügt wie 3 b). Merkwürdig ist nun ת ת 6 , mit dem es das gleiche Prädicat hat, insofern, als man weder begreift, weshalb der Verfasser den unbedeutenden Zug in wenig veränderter Form wiederholte, noch תרום wählte (vgl. Ps. 42, 8), vielmehr eines Wortes sich bediente, welches sonst nirgends vom Meer oder der Meeresströmung gebraucht wird, während umgekehrt ein grofser Strom die Bezeichnung „Meer" erhalten kann. Zwar übersetzt man Ps. 42, 2 נהרות (Grätz : „Ströme ${ }^{\star}$ ) gewöhnlich durch „Gewässer ${ }^{\star}$ im Parallelismus zu dem vorauf-

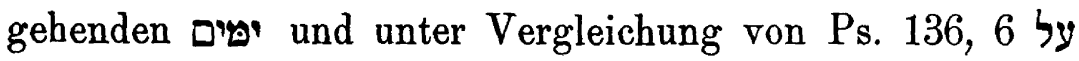
המים; allein ebenso wie dem Verfasser von Ps. 24 die Erde (die Küsten) auf dem Meer, konnte sie (ein Theil des Binnenlandes) ihm auch auf die grofsen Ströme gegründet erscheinen, eine Anschauung, zu der wohl nicht wenig die Beobachtung von Meeres- und Flufsinseln u. ä. beigetragen hat. Gewifs hat der Dichter unseres Liedes die von ihm geschilderte Gefahr mit einem Strome ver- 
glichen, in dessen Tiefe (מצולה, vgl. כל מצולות יאור Sach. 10,11) ein Unglücklicher (vielleicht er selbst) gerathen war; ein Späterer, der unsern Psalm auf Jonas Schicksal bezog oder vielmehr schon bezogen fand, schob, um die Deutung von נהר auf einen Strom (im eigentlichen Sinne) abzuweisen, in 4 die Wendung בלבב יטים ein. Anders verfuhr der Interpolator von 6 und 7, der wahrscheinlich diesen Zusatz noch nicht kannte. Er nahm an der Tradition in 4 keine Aenderung vor, erklärte aber das ihm auffallende 'תהום יס' (vgl. Ps. 42, 8 a) und malte die Situation des bis auf den Meeresboden Untersinkenden weiter aus, indem er Ps. 18 wie auch Jes. 38 (חָיבי , heranzog, Stellen, aus denen auch der ältere Schriftsteller Reminiscenzen angebracht hatte. Einiges (s. später) spricht dafür, dafs dieser Ergänzer des Liedes derselbe war, der das Gedicht mit der Einleitung V: 2 (2a (יה' אלהי 7 in das Buch Jona verpflanzte. (Das den zweiten Halbvers in 4 überladende נגליך würde man als Glossem zu dem seltenern משכריך gern beseitigen, wenn es nicht schon Ps. $42,8 \mathrm{~b}$ vorkäme; freilich kann man die Aechtheit desselben wenigstens an letzterer Stelle anzweifeln). Nach der Ausscheidung von $6 \mathrm{f}$. aus dem ursprünglichen Psalm ergiebt sich ein passender Anschlufs von 8 an 5. „Ich vermeinte schon aus deinen Augen weggerissen zu sein, deinen heiligen Tempel nie mehr zu erblicken - da, als meine Seele in mir verschmachtete, gedachte ich an Jahve", eben den Herrn des Tempels, der die Macht hat die Bitten der Elenden zu erfüllen. - An den Ausfall eines oder mehrerer Worte vor ותשליכני V. 4 hat man wohl nicht zu denken, so wenig die Anreihung mit I statt mit כי (und folgendem Perfect) gefällt. - In 5 b möchte das für ${ }^{\prime}$ vorgeschlagene $\times$, welches in defectiver Schreibung nicht existirt, aus dem Grunde unpassend sein, weil man wohl die Klage ${ }_{\infty}$ leider werde ich nicht" u. s. w., aber nicht die Frage „wie soll ich (unter diesen 
Umständen) den Tempel wiedersehen ? ${ }^{\star}$ erwartet. Die Verbindung אך ist ungewöhnlich; daher hat man wohl das etwa durch den Schlufs von איניך verdorbene א einzusetzen, welches allerdings Hitzig und auch Stein er verschmähen, dieser unter Hinweis darauf, dals schon Theod. Ts las; doch vgl. die positive Aussage Jes. 38, 11 - - Das Ver. bum נגרשתי V. 5, wofür wir in Ps. 31, 23 jetzt (das aus

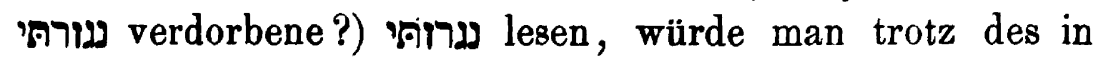
Klagel. 3, 54 stehenden ערח geneigt sein, in jenen Ausdruck der Psalmstelle zu verwandeln, wenn nicht die Möglichkeit vorhanden wäre, dafs das נגרשתי unseres Buches eine Erklärung des schon vom Dichter in Ps. 31 vorgefundenen נגרותי sein soll. - Anstofs nehme ich endlich an קצבי V. 7, da Kön. 6, 25. 7, 37 Gestalt, Form bezeichnet. Steiners Erklärung קצב מטכ sowohl wied. im Hebr. und Arab. ursprünglich schneiden, abschneiden, קֶֶ. also Abschnitt, dann Ende; vgl. קצ und $\mathrm{Ki}$. richtig : "קצב וקץ אחד הוא ist zu verwerfen; wozu hätte die Sprache, die neben poch Bildungen von perwandter Bedeutung besals, ein pֶֶ: neu schaffen oder im Sinne von pe gebrauchen sollen? "Die LXX mit ihrem

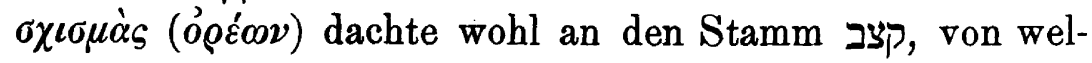
chem Formen in 2 Kön. 6, 6. Hohel. 4, 2 durch $\alpha \dot{\pi} \varepsilon \dot{x} \chi \nu \iota \sigma \varepsilon$,

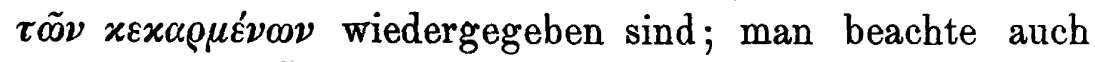

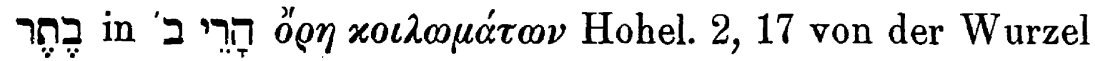
בחרון Gen. 15, 10 בתר der $\varrho \alpha \gamma \alpha \dot{s} \varsigma$ von $\varrho r_{\gamma}^{\prime} \gamma \nu v \mu \iota$ vergleicht. Aber der Dichter von Jon. 2, 7 hat vermuthlich קצוי ארץ nach (Ps. 48, 11. 65, 6. Jes. 26, 15) geschrieben, da es sich hier.nicht um die Schluchten der Berge, sondern um das Hinabreichen ihrer Tiefen bis in das Meer handelt. Ps: 18, in Jon. 2 mehrfach benutzt, bietet V. 8 מוסרי הרים, die Vulgata im'Jona das wohl errathene extrema montium. Wie ich aus Grätz Psalmencommentar I, 122 ersehe, hat 
schon Abraham der Babylonier obige Aenderung vorgeschlagen, welche auch Grätz billigt.

Die Abweichungen der LXX vom massor. Text in den beiden ersten Capiteln unseres Buches sind, abgesehen von der Auslassung des mit באשר beginnenden Satzgliedes 1, 8, für die Kritik ohne Werth. Ich übergehe sie daher, indem ich nur noch bemerke, dafs ich einigen der von Vollers in dieser Zeitschrift 1884 S. 18 ff. ausgesprochenen Vermuthungen über den Text, der dem griechischen Uebersetzer vorgelegen habe, nicht beistimmen kann. So halte ich $\pi \alpha \rho \varepsilon \beta \iota \alpha ́ \zeta o \nu \tau o ~ 1,13$ aus dem Zusammenhange conjicirt, wohl unter Berücksichtigung von חתר „mit Gewalt einbrechen" (Vollers : Vielleicht las S ויתחרו, wozu

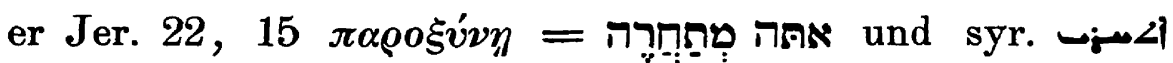

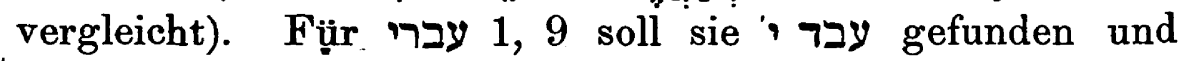
den Kürzungsstrich übersehen haben, vielleicht in Erinneעברי עung an 2 Regg. 14, 25; aber sie hat sich wohl ein oder gar עבד nach der Umgebung des Wortes zurechtgelegt.

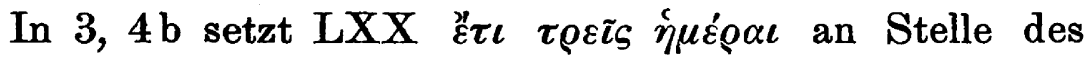

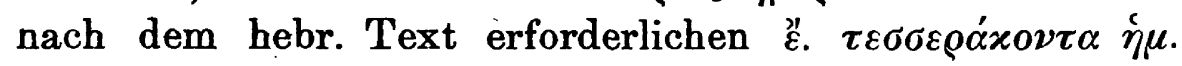
Wir sehen darin nicht einen Irrthum des griechischen Uebersetzers noch ein Versehen in seiner hebräischen Vorlage ( sowohl im Palmyrenischen als im Syrischen sind die Zeichen für 3 und 40 nicht gut zu verwechseln* Vollers a. a. O. S. 20), sondern nur die Nachlässigkeit eines Ab-

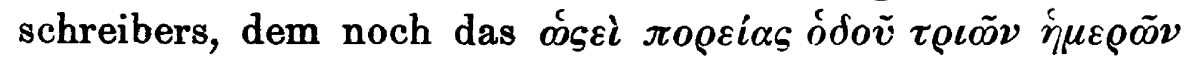
V. 3 im Sinne lag. - Von Wichtigkeit für unsere Untersuchung ist der meines Wissens bis jetzt übersehene. Unterschied der Darstellung in V. 5 und 6 ff. Nach $\check{~ g l a u b e n ~}$ die Leute von Nineve auf Jonas Predigt Gott (oder an Gott), rufen ein Fasten aus und legen, Jung und Alt, Trauergewänder an. "Nach 6 ff. gelangt „das Wort" an den König, und dieser thut Bufse (was ausführlich beschrieben wird) - man denkt, ebenso wie seine Unter- 
thanen, die ihm darin vorangegangen sind. Allein nun erläfst der Furst in Bezug auf Fasten. Travern und Beten (welches letztere in 5 nicht genannt ist) ein Edict, dessen Bestimmungen nicht nur mehr verlangen, als die Nineviten in den von ihnen aus eigenem Antrieb veranstalteten Bufsübungen thun, sondern auch so lauten als ob von der Einwohnerschaft noch nichts geschehen wäre, um Gott zu versöhnen. Einem etwaigen Versuch, V. 5 umzustellen (hinter 9), widersetzt sich צום 5 , da die Ansetzung eines Fastens durch das Volk nach der ausdrücklichen Anordnung desselben durch den König überflüssig, das Beten zu Gott aber בחוקה, auf welches der Herrscher kein geringes Gewicht legt, in der Ausführung bei der Aufzählung dessen, was die Nineviten gethan, gar nicht erwähnt sein würde. Hätte in diesen Versen Jemand eine überkommene Schrift mit eigenen Zusätzen ausgestattet, so würde er die Bekehrung des Volkes erst hinter 9 geschildert, 5 aber an seiner jetzigen Stelle gestrichen und höchstens in veränderter Gestalt nach 9 verwendet haben. Da ferner V. 6-9 für eine Randbemerkung zu umfangreich wäre, so vermag ich mich des Gedankens nicht zu erwehren, dals hier von einem Redactor in einer ungeschickten Weise Bruchstücke aus zwei Schriften zusammengefügt sind, welche denselben Gegenstand behandelten, dabei jedoch, wie in der Sache, so auch im Ausdruck

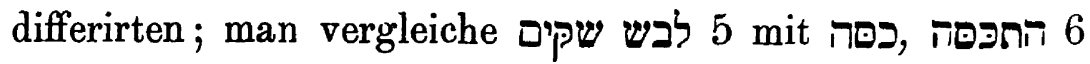
und 8 bei gleichem Object. Daraus folgt weiter, dafs der Redactor einen doppelten Bericht über Gottes Befehl an Jona und die Vollziehung desselben, über die Bufse der Nineviten wie über die Reue Gottes vor sich gehabt hat. Von einer Fortsetzung der Scheidung beider Berichte innerhalb des Cap. 3 stehe ich indessen vorläufig $a b$, da einige hierbei in Betracht kommende Punkte sich besser in einem anderen Zusammenhang erörtern lassen, und beschränke mich vorzugsweise darauf, den Text von mehreren 
Interpolationen zu reinigen. Als solche betrachte ich die

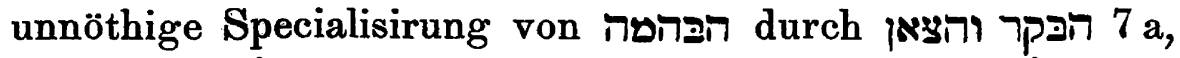
sodann אל-יטעטו מאוטה $7 \mathrm{~b}$, whelches schon in halten ist, aber wohl kaum das überaus harte Verbot ומים הארם Dafs zu אלם-ישתו 8 verständiger Weise nur ויקראו als Subject gedacht werden kann, bemerkt auch Hitzig; hat etwa der ursprüngliche Erzähler das התכסה שקים auch nur von den Menschen gemeint, ein Späterer aber seinen wegen des Mangels eines הארם ungenauen Ausdruck durch die Einschiebung von הארם והפהמם In 7 unterbricht die Angabe משעם הפלך וגרלי (דפו störend die

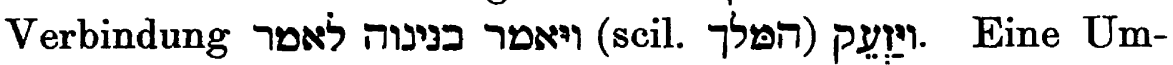
setzung jener Worte, etwa in den Anfang der directen Rede, ist nicht rathsam; sie stammen wohl (incl. לאפר) von einem Leser, der für einen Befehl des Königs die Zustimmung der Grofsen des Reiches und die ausdrückliche Erwähnung dieser Zustimmung für unerläfslich hielt oder durch dieselbe in diesem Falle der Verordnung des Fürsten besonderen Nachdruck verleihen wollte. (Vocalisirte er etwa Pirn als Kal und ergänzte als das Subject ${ }_{n}$ der Herold “? Dann würde sich die Wiederholung des השלך um so leichter erklären.)

Die Differenz in ויכס ist wohl nicht durch Abänderung der ersteren Form in das Hithpael auszugleichen. In ו 7 scheint das überlieferte Hiphil in dem hier verlangten Sinne ${ }_{n}$ er liefs ausrufen ${ }^{4}$ allein richtig ${ }^{1}$ ). Die Vocalsetzung in טֵַِ statt des biblisch-aramäischen טي̣ (assyr. têmu) mag man, wenn man darin nicht einen Irrthum sehen will, durch die Annahme rechtfertigen, dafs

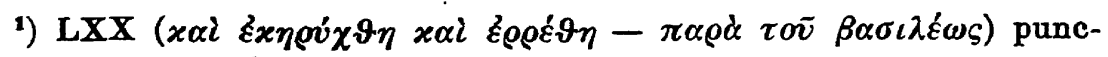
tirte wahrscheinlich יהוח fehlte,

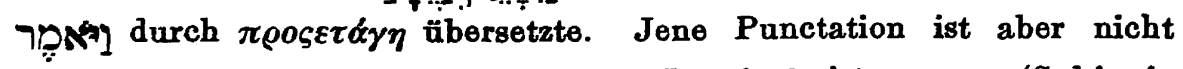

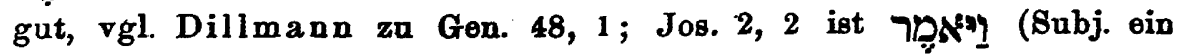
Bote) oder vielmehr ebenso wie in Gen. 48 ing zu emendiren.

Zeitschrift f. d. alttest. Wiss. Jabrgang 7. 1887. 
die Hebräer bei der Uebernahme dieses term. techn. der Verwaltung in ihre Sprache ihm diejenigen Vocale verliehen haben, welche das Wort bei ihnen in der Bedeutung ${ }_{n}$ Geschmack, Einsicht" bereits hatte ${ }^{1}$ ).

Nach C. 4, 1 ff. ist Jona ärgerlich, dafs Gott die Stadt nicht zerstört, und beklagt sich deshalb bei ihm; auf Jahres Frage aber, ob er „recht" zürne, bleibt die Erwiderung des Propheten aus. Dieses sein Schweigen ist unverständlich, zumal nach seiner längeren Expectoration in V. 2, und in der That giebt er in 9 auf die gleiche Frage Gottes trotz seines Unmuths Antwort. Dals ein Redactor die Aeufserung des Jona strich, weil sie ähnlich lautete wie die in 9 , wird Niemand glaublich finden. Erinnert man sich nun, da/s in 1 Kön. 19, einem Capitel, das wohl schon zur Zeit des Buches Jona mehrere Interpolationen enthielt, Elia zweimal von Jahve über dieselbe Sache gefragt wird (V. 9.13) und zweimal dieselbe Antwort ertheilt, so kann man zu der Ansicht neigen, es möchte hinter Jona 4, 4 eine ähnliche Entgegnung des Propheten wie die in $9 \mathrm{~b}$ berichtete, etwa durch eine Art von Homoioteleuton ausgefallen sein. Nach dieser Hypothese mülste der Erzähler hinter der Versicherung des Jona die Unterredung Gottes mit demselben abgebrochen haben, weil sie ja doch in 9 wieder aufgenommen und zu Ende geführt werden sollte. So wunderlich uns ein solches Verfahren auch dünken mag (in 1 Kön. 19 ist durch die Eingangsworte von V. 11 der Uebergang von der Interpolation zu der

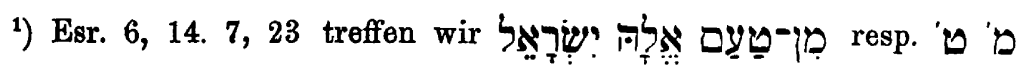
אִ $N$ an. Möglich, dafs der Punctator an diesen Stellen, den einzigen, die von einem ay Gottes reden (und schwerlich dem ältesten Text angehören), durch die Verschiedenheit der Vocale den Unterschied zwischen einem göttlichen und menschlichen טעa (letzteres andeuten wollte; dafs aber der Autor jener Wendungen selbst beide Male nur das gewöhnliche ich, kann kein. Zweifel herrschen. 
älteren Erzählung vermittelt), so weifs man doch nicht, ob man dasselbe nicht einem Schriftsteller aus der Epoche des jüngeren Hebraismus zutrauen darf; indessen läfst sich noch eine andere Erklärung des in Rede stehenden Verses finden. Vor allem ist er entbehrlich; wird doch die Handlung selbst in dem Falle nicht weitergeführt, dafs man in der oben angegebenen Weise einige Worte ergänzt. Ja es träte bei dieser Ergänzung der weitere Uebelstand ein, dafs der Prophet mit seinem trotzigen היטב חרה לי das letzte Wort und somit scheinbar Recht behielte, da Jahve eine künftige Sinnesänderung des Jona nicht einmal andeutet (anders erwarten wir es 1 Kön. 19, 11). Fehlt V. 4, so hüllt sich Jahve bei dem Vorwurf des Propheten in Schweigen, offenbar, weil er diesen später von der Richtigkeit seines Verfahrens zu überzeugen hofft. Derjenige jedoch, welcher V. 4 einsetzte, war der Meinung, Jahve dürfe die Klage und Anklage des Jona nicht ruhig hinnehmen, und so gebrauchte er, mochte er sich nun vor einer stärkeren Umgestaltung des Textes scheuen oder ihm grade nichts Passenderes beifallen, für die Antwort Jahves die in V. 9 mitgetheilte, dort auf eine ähnliche Aeưfserung wie $3 \mathrm{~b}$ sich beziehende Rede Gottes. Damit dals Jahve überhaupt das Wort ergriff, war der Intention des Verfassers von V. 4 genügt, und wir bedürfen nicht der Hypothese, dafs der zweite Theil seines Einsatzes ausfiel, oder dafs er durch V. 4 dem Leser habe andeuten wollen, derselbe möge sich die Fortsetzung des Gesprächs nach V. 9 selbst ergänzen. (Sollte er etwa gewünscht haben, dafs Jahve des Propheten Klage mit Spott abfertige, indem er die aus V. 9 aufgenommene Frage in dem Sinne verstand : „bist du recht. böse ${ }^{\text {( }}$ ?). - So wenig wie V. 4 machten 2 und 3 einen Bestandtheil des ältesten Berichtes aus. Allerdings lernen wir durch Jonas Rede das Motiv seiner Flucht vor Jahve kennen, welche der Darsteller in 3,1 nicht begründet hatte; aber, wie Hitzig richtig ge- 
sehen hat, der in 4, 2 f. angegebene Grund ist ein ganz anderer als der oder die von uns vorausgesetzten. Wer 1, 3 liest, ohne Kenntnifs von 4, 2 f. zu haben, sucht sich, freilich kopfschüttelnd, den Ungehorsam des Propheten etwa so zu erklären, dafs dieser nicht gesonnen war in einem Reiche, von welchem schon zu seiner Zeit Israel Gefahr drohen, und dessen Untergang er im Interesse seines eigenen Vaterlandes wünschen mochte, seine warnende Stimme zu erheben und im Falle des Erfolges zu der Erhaltung und Kräftigung eines furchteinflöfsenden oder verhalsten Volkes beizutragen. Blieben dagegen die Heiden, zumal die Bewohner der grofsen Stadt Nineve, für seine Mahnungen taub - und das war höchst wahrscheinlich sollte er sich da dem Hohn und der Verachtung, vielleicht gar der Lebensgefahr unter ihnen aussetzen? Konnte ihn ferner nicht ein dankbarer Wirkungskreis (von einem Eintreffen seiner Orakel berichtet 2 Kön. 14, 25), die Liebe zu Freunden und Verwandten (vgl. Gen. 12, 1) u. a. an die Heimath fesseln? Dals Jona den Befehl Jahves deshalb nicht vollziehen wollte, weil er wufste, dieser werde das von dem Propheten zu verkündende Strafgericht nicht eintreten lassen, das vermögen wir um so weniger zu ahnen, als wir nirgends, auch an unserer Stelle nicht, Aufschlufs darüber erhalten, welche Erfahrungen und Reflexionen denn in Jona den Glauben erweckten, Jahve werde an dem heidnischen, lasterhaften Nineve seine Drohungen nicht erfüllen. Hatten andere Propheten, denen von Jahve geheifsen wurde, den Gottlosen die Bestrafung zu weissagen, die Langmuth und die schonende Liebe Gottes gegenüber dem Sünder nicht gekannt, hatten sie gar, wenn sie sich derselben erinnerten, gegen die Ausführung des göttlichen Willens sich gesträubt? Statt Jahve durch seinen Fluchtversuch zu erzürnen, hätte Jona, als die Aufforderung desselben an ihn erging, freimüthig und doch bescheiden (etwa nach Art des Mose) seine Einwendungen und Be- 
denken vorbringen sollen; mufste doch der Auftrag 1, 2 schon an sich den Propheten in Erstaunen setzen; denn „kein Prophet vernahm jemals den Befehl, in ein fremdes, etwa weitentlegenes Land, um es zu bedrohen, zu gehn und konnte ihn nicht vernehmen. Weissagend über fremde Völker, blieben die Propheten im Lande" (Hi tzi ig-S t ein er S. 172). Aber unbekümmert darum, dafs diesen und ähnlichen Erwägungen ein denkender Leser an der Stelle 1, 3 sich nicht verschliefsen konnte, dafs das dort geschilderte Verhalten des Jona eine sofortige Begründung verlangte, falls es nicht eigensinnig, thöricht und vollends bei einem Propheten unverzeihlich erscheinen sollte, war der erste Erzähler nach den Worten אוניקם, nach denen ein mit

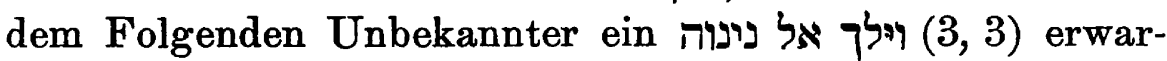
tet, fortgefahren-mit לברח מלפני יהוה. Er brauchte eben, mag er darin einer Sage gefolgt sein oder nicht, den Ungehorsam und die Flucht des Jona in das Ausland, sogar über das Meer (daher er ihn nicht in Palästina trotzig bleiben liefs), um auf merkwürdige Weise die Entdeckung des Frevels und die Bestrafung des Frevlers durch Jahve herbeiführen zu lassen, ehe der Prophet sich dazu bequemte, das Wort desselben den Nineviten zu verkündigen. Nach meinem Dafürhalten hätte der originale Verfasser von Cap. 1 selbst dagegen nichts gehabt, dafs Jemand sich bei der Lectüre von 1, 3 mit dem oberflächlichen Gedanken zufrieden gab : wenn so Mancher Gottes Gebot übertreten hat, warum sollte das nicht auch ein Prophet einmal gethan haben (vgl. die allerdings durch eigenthümliche Umstände veranlafste Uebertretung eines Propheten 1 Kön. 13)? Dafs einem solchen Darsteller sich die Nothwendigkeit wenigstens einer nachträglichen Begründung für das frühere Verhalten des Jona aufgedrängt, und dafs er diese Begründung dann in der uns 4, $2 \mathrm{f}$. vorliegenden Weise gegeben habe, ist unwahrscheinlich. Dagegen hat, wie vermuthlich schon Andere vor ihm, der Autor von 4, 2 f. 
an 1, 3 begründeten Anstofs genommen und sich bestrebt die ehemalige Handlungsweise des Propheten zu entschuldigen. Für seinen Zweck hat er hauptsächlich die Schlufsworte des dritten Capitels sowie die spätere Verhandlung Jahves mit Jona benutzt, bei welcher der erstere sein Erbarmen mit dem Sünder hervorhebt. Das Unzutreffende und Unzulängliche seines Versuchs steht ungefähr auf gleicher Linie mit der verkehrten Motivirung, welche der Schreiber von 1, 14 für das Thun der Seeleute sich erdacht hat, die den Propheten als „unschuldig“ bezeichnen müssen; weiter unten wird sich zeigen, dafs beide Einschiebungen von demselben Schriftsteller herrühren.

Wir haben jetzt das Verhältnifs von 4, 1 zu 4, $5 \mathrm{zu}$ untersuchen. Nach V.1 ist Jona sehr böse, und zwar, wie man gewöhnlich annimmt, deshalb, weil Gott seine Drohung nicht wahr macht; der Prophet weifs also bereits, was dieser gethan - und das kann er erst am Ende der 40 Tage $(3,4)$ wissen - ja, der Ergänzer läfst ihn Jahve darüber Vorhaltungen machen. Wie vereint sich diese Angabe mit der in V.5, dafs Jona in einer selbsterbauten, jedenfalls für einen längeren Aufenthalt eingerichteten Hütte aufserhalb Nineves bleibt „um zu sehen, was in (mit) der Stadt geschehen werde"? Wegschaffen würde man diesen Widerspruch nicht durch die Annahme, Jona möchte von Unmuth ergriffen worden sein, als Jahve ihm noch vor Ablauf der Frist die Aenderung seines Entschlusses in Betreff der Stadt offenbart habe. Dann war das Abwarten des Propheten zwecklos; oder glaubte er nicht, dals es Jahve mit einer solchen Aeufserung Ernst sei? Uebrigens hätte weder ein Erzähler eine hierauf bezügliche Mittheilung unterlassen, noch der Redactor sie beseitigt. Die wider alle Vermuthung eingetretene Bekehrung der Nineviten konnte dem Jona als Wirkung seiner Predigt an sich nicht unangenehm sein; mifsfiel sie ihm etwa deshalb, weil er vermuthete, dafs Gott die Stadt jetzt nicht werde 
untergehn lassen, und weil er so Gefahr lief, als ein falscher Prophet zu erscheinen? Aber da ihm Gottes Entscheidung nicht bekannt war, da er eine Zeit lang eine abwartende Haitung annehmen und da nach der bestimmt und bedingungslos $(3,4 \mathrm{~b})$ auf Gottes Befehl $(3,2 \mathrm{~b})$ ausgesprochenen Drohung der Gedanke an ein strenges Strafgericht über Nineve ihm am nächsten liegen mufste - wie konnte da sein Mifsvergnügen so aufserordentlich sein wie unser Text es im ersten Verse schildert? Durch den so leicht sich darbietenden Vorschlag einer Umstellung von 4, 5 vor 4, 1 wird den Schwierigkeiten nicht abgeholfen. Nicht nur schliefst V. 1 ungezwungen an 3,10, und ebenso 4, 6 an den Inhalt von 4, $5 \mathrm{a}$ an, sondern man würde auch bei jener Versetzung innerhalb derselben Schrift eine Angabe vor 4, 1 oder (etwa mit כי, כweil ${ }^{\star}$ ) hinter diesem Verse vermissen, dafs oder wodurch Jona die Aufhebung des göttlichen Gerichtes erkannte oder erfuhr. Während aber 3, 10. 4, 1. 5a. 6, was die Reihenfolge der Handlungen betrifft, sich zwanglos aneinander fügen, besteht zwischen $5 \mathrm{~b}$ und 6 in der That eine Lücke, da $6 \mathrm{f}$. die hier nicht mitgetheilte Verschonung der Stadt und die Kenntnifs des Propheten von diesem Umstande zur Voraussetzung hat. Eine Athetese des unbequemen Halbverses 4, $5 \mathrm{~b}$ wäre ein kritischer Gewaltstreich; aber auch zu der Annahme eines Ausfalls nach 4,5 im jetzigen Text, mit dem Inhalt ,und es sah Jona, dafs Gott Nineve verschonte, und das verdrofs ihn sehr" werden wir uns um so weniger entschliefsen, als schon der in V. 1 erzählte Unmuth des Propheten auf eben jenem Wissen von der Errettung Nineves beruht. Vielmehr haben wir in unsern Versen nicht nur eine Verschiedenheit der Quellen, sondern auch eine üble Zusammenarbeitung ihrer Mittheilungen durch einen Redactor zu constatiren, und erinnern hinsichtlich des letzteren Punktes vorläufig an unsre Bemerkung über die Stellung von 3, 5. - Eine andere Differenz zwischen den Erzählungen werden 
wir bei der Vergleichung von 4,5 und 4, 6 gewahr. Jahre (Elohim) schafft nach V. 6 einen Kikajon, um Schutz ürer dem Haupte (nicht : uber der Hütte) des Propheten zu werden, während nach V. 5 Jona sich ein Sichirmdach errichtet und im Schatten unter demselben " wohnt ( $\nabla \mathrm{gl}$.

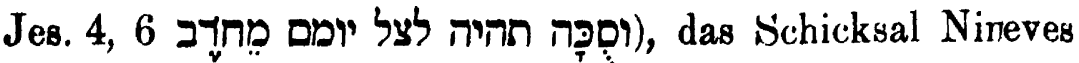
von hier aus abwartend. (Nach Hitzig S. 173 nverräth sich das Gebilde der von nichts Ueberkommenem beengten Phantasie durch die Ueberfruchtung gegen das Ende", wozu er aufser Theilen von 4, 10 f. auch unsere Verse rechnet). Hält man diese Abweichung in der Darstellung mit der oben in 4, 1 und 4, 5 beobachteten zusammen, so gelangt man zu folgendem Ergebnifs. Nach der einen Schrift hat Jona, als Jahve wegen der Bekehrung der Nineviten nach Ablauf von 40 Tagen statt des Rechtes die Gnade walten liefs, im Aerger die Stadt verlassen. Da läIst Jahve scheinbar absichtslos zur Freude des unter der Hitze leidenden, also unter freiem Himmel sich aufhaltenden Propheten einen Baum zu einer beträchtlichen Höhe wachsen (vgl. 1 Kön. 19, 4 וישב חחת רתם אחד nach dem Keri), an dessen plötzliches Verdorren der gegen die heidnische Stadt barmherzige, aber nicht minder seinem Propheten gegenüber langmüthige Gott eine eindringliche Belehrung knüpft. Die Relation der zweiten Vorlage gab dagegen an, dafs Jona, nachdem er den Untergang geweissagt, (noch vor dem Ende der bestimmten Frist) sich aus der Stadt begab, welche, um den Zorn der Gottheit abzuwenden, die gewaltigsten Anstrengungen traf, und dafs er eine Laube baute, der Dinge harrend, die da kommen sollten. Mit der Erzählung, dals Nineve nicht zersțört wurde, kann diese Quelle nicht geschlossen haben; auch ihr Autor wufste vom Unmuth des Propheten sowie von der merkwürdigen Staude zu berichten, dachte sich dieselbe aber in der Nähe der Hütte des Jona oder höchstens den Propheten bisweilen im Schatten des Gewächses vor seiner 


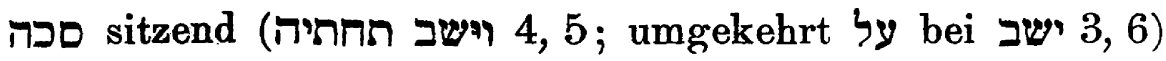

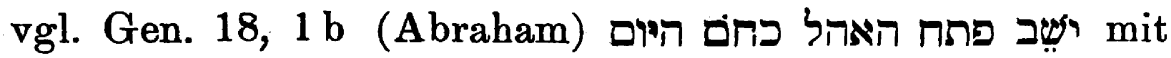

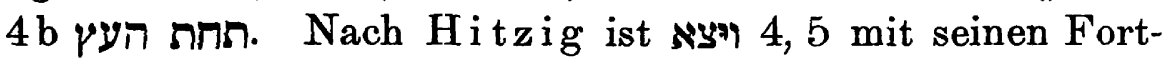
setzungen, $\rrbracket^{\text {wenn }}$ man einige Ordnung herstellen will ${ }^{\star}$, als Plusquamperf. zu fassen, "siehe zu 2, $4^{\text {* }}$ (auch $\mathrm{S}$ t e in er z. St.), und er macht, wie schon oben erwähnt, dem Verfasser den Vorwurf, dafs er den Propheten erst in $\tilde{0}$ aus der Stadt gehen lasse, in der Absicht zu erfahren, was er bereits wisse. Aber) die Schuld an der Verwirrung trifft einzig und allein den Redactor, der nach 4, 1 und 4, 5 a (das Verlassen der Stadt mufs auch in seiner Hauptvorlage gestanden haben) spätestens in $4,5 \mathrm{~b}$ sich seiner zweiten ausführlicheren Quelle zuwandte. - In 4,6 ist להציל לו מרעתו befremdlich, da das Gewächs und die von demselben ausgehende Beschattung nicht den Zweck hatte, den Propheten von seinem Unmuth zu befreien. Schwerlich ist die Phrase aus einer Quelle geschöpft, sicher nicht aus derselben, welcher der vorhergehende Infinitiv entstammt, sondern wohl der Zusatz eines Lesers, der in dem Aufwachsen der Wunderpflanze einen hervorragenden Beweis der Freundlichkeit Gottes sah. - Ob die beiden Zeitangaben לפחרת und von einem oder von verschiedenen Verfassern herzuleiten sind, ob beide (für das Verständnifs nicht absolut nothwendig) schon von dem ältesten Darsteller geschrieben wurden, ist sehr unsicher; vermuthlich fand die Notiz בעלות השחר schon derjenige vor, der, wie wir sehen werden, 8 a einsetzte. Aus V. 9 erfährt man, dafs Jona über das plötzliche Eingehen des herrlichen Gewächses bis zum Tode betrübt war (ער־מות bot wohl schon die ursprüngliche Schrift). Uebergeht man beim Lesen zunächst V. 8, so wird man die Stimmung des Propheten darauf zurückführen, dafs ihn dieser Vorfall an die Vergänglichkeit alles Irdischen mahnte, auch desjenigen, welches wegen seiner anscheinenden Kraft und Festigkeit eine längere Dauer seiner 
Existenz verheifst und um seiner Schönheit willen sie verdiente (vgl. Sah er überdies in dem Untergange des Kikajon das Wirken der Gottheit, so mochte es ihn leicht bedünken, als ob diese, nachdem sie ihn schon durch die Nichterfüllung des Orakels in seiner Prophetenehre verletzt, ihm nicht einmal die harmlose Freude an der prächtigen Pflanze gegönnt habe. Im Widerspruch hiermit heifst uns 8 a den Grund für den Lebensüberdrufs des Propheten (einen Grund, der auch 1 Kön. 18 bei Elia rein geistiger Art ist ${ }^{1}$ )) in einem auf sein körperliches Befinden einwirkenden Umstand suchen, insofern Jona nach dem Welken des ihm erquickenden Schatten gewährenden Baumes von der Hitze übermälsig geplagt wird. Ja, diese Hitze soll von Gott selbst um des Jona willen durch einen dörrenden Ustwind veranlafst oder, wenn man will, verstärkt worden sein. Allein die Sendung des Gluthwindes ist eine unnöthige Peinigung des Propheten, die mit der Absicht Jahres, ihn durch das, was mit dem Wundergewächs vorgeht, zu belehren, in keinem Zusammenhang, mit der Nachsicht und herablassenden Güte, welche Gott nachher gegen den milsmuthigen und trotzigen Propheten zeigt, sogar in scharfem Contrast steht. Wahrscheinlich ist 8 a nicht derjenigen Quelle entlehnt, welche von dem Bau der Hütte berichtete; in die Hütte konnte sich ja Jona nach dem Vertrocknen der Pflanze bei zunehmender Schwüle leicht zurückziehn. Dafs aber auch die andere Vorlage des Redactors unsern Halbvers nicht enthielt, läfst sich sprachlich erweisen. An den drei anderen Stellen des Buches, an denen uns מִנְּה be-

1) Bei dieser Gelegenheit bemerke ich, dafs die Worte 7חא 1 Kön. 19, 5 die an falsche Stelle gerathene, richtige Correctur

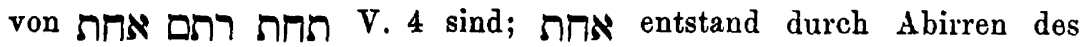
Schreibers auf das $\Pi$ in

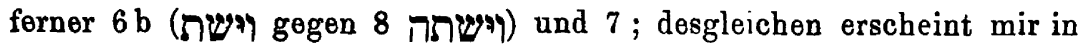

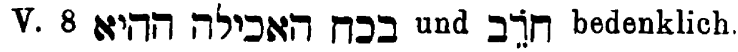


gegnet - und wir haben keinen Grund, dieselben nicht als Bestandtheile der erwähnten Schrift anzusehen - ist das Subject des auf וימן folgenden Verbs, welches letztere im Infinitiv $(2,1)$ oder mit Waw consec. Imperf. $(4,6.7)$ angefügt wird, identisch mit dem Object von וימן; in 4, 8 a dagegen tritt nach ות ות השמש in neues Subject ein, dessen Ausscheidung der Text nicht gestattet, da הכה vom Winde nicht üblich ist ${ }^{1}$ ). Vermuthlich würde der erste Darsteller, wenn er mit ותך השמש fortzufahren willens war, ein von וימן verschiedenes Zeitwort, etwa שלח (2), הטיל, wie 1, 4, mit בארץ) רוח vorausgeschickt haben; auch hätte er, der das Stechen des Wurms durch הפּה את ausdrückt, das der Sonne wohl in gleicher Weise, nicht durch הפה על , bezeichnet; siehe das, allerdings in der Poesie und mit dem Suffix. stehende sich der Verf. von 8 a nach 7 gerichtet; dem ורימן ויויתעלף , ותר , וימן Reranlassung zur Einschiebung von 8 a gab wohl weniger die Meinung des Autors, dals die üble Stimmung des Jona durch V. 7 nicht genügend motivirt sei, als vielmehr seine Absicht, den sich gegen Gottes Anordnung nun schon wiederholt auflehnenden Propheten durch Gott empfindlicher strafen zu lassen als es von diesem später in Worten geschieht. Vielleicht ist er derselbe wie der die Freundlichkeit der Gottheit betonende Urheber der Wendung להציל לי מרעתו

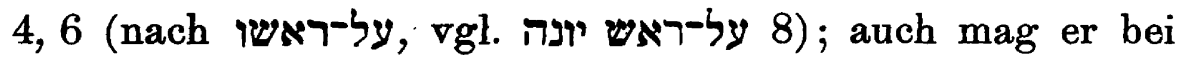
2, 8 sich erinnert haben. - Ueber die letzten Verse spricht sich Hitzig S. 173 dahin aus : „Die Argumentation in 10 und 11 erzeugt in ihrem Verlaufe noch zwei weitere Argumente, welche nicht zur vollen

1) In Ges. Lex. finde ich freilich unter von der Sonne, dem Winde Ps. 102, 5. Hos. 9, 16“; aber an beiden Orten ist nur an die gewöhnliche Ursache des Verdorrens, den Sonnenbrand, zu denken. 
Entwicklung kommen." Nach der bisherigen Untersuchung wird es klar sein, dafs, wie das Entstehen, so auch das Vergehen des Baumes, die Verstimmung des Jona, Gottes Frage und Selbstrechtfertigung in beiden Quellen enthalten war. Aber die Scheidung dessen, was diesen angehört, wird uns hier dadurch erschwert, dafs die Möglichkeit der Erweiterungen von anderer Hand, wie wir dergleichen im Fortgang unserer Betrachtung wahrgenommen haben, mit ins Auge zu fassen ist. So steigen mir $Z$ weifel auf, ob man ובהמה רכה V. 11 der Hauptquelle im Jona zuweisen darf. Bei der etwaigen Vernichtung der Stadt kam für den ursprünglichen Erzähler das Vieh, auf welches er in 3, 5 keine Rücksicht nahm, meines Erachtens schwerlich in Betracht; stammt nun obige Angabe von dem andern Darsteller ebenso wie im Anfang von 3, 7b האדם והפהמה, oder wurde sie von Jemand, der diesen Vers gelesen, vielleicht auch in 3, 8 dieselben Worte wiederholt hatte, in 4, 11 eingefügt und zwar an den Schlufs gebracht, wo die Kürze des Ausdrucks gegen die Länge des auf die Menschen sich beziehenden Passus in auffälliger Weise absticht? - Da der Haupterzähler von Cap. 1 einige Male verwendet hat (בשלמי ,בשלי), der andere Schriftsteller aber in Cap. 3 und 4 nicht, so wird man es für richtig halten, $10 \mathrm{~b}$ von jenem abzuleiten; indessen darf man diesen Ursprung schon deshalb nicht für unbedingt sicher ausgeben, da auch ein Leser, welcher בעלות השחר in 7 vorgefunden (wenn nicht gar geschrieben) hatte, es für nöthig erachten mochte, auf die kurze Existenz des Gewächses hier hinzuweisen, wenn dies in der ihm vorliegenden Schrift (resp. den Schriften) noch nicht geschehen war; aufserdem ist ja • befremdet es, dafs dasjenige Moment der Argumentation, welches wir an erster Stelle erwarten, die Hervorhebung der Werthlosigkeit jener so rasch vergehenden Pflanze im Verhältnifs zu der Bedeutung der alten Stadt und ihrer 
Bewohner, seinen Platz erst hinter dem andern Moment hat, einem Moment, an welches man nicht leicht denkt, nämlich dafs Jona zum Wachsthum der Pflanze nichts beigetragen hat, während Nineves Grölse das Werk Jahves ist. Klarheit über $10 \mathrm{~b}$ bringt erst eine neue Beobachtung über פִ. Wenn wir den oben als Zusatz erwiesenen Halbvers 8 a nicht berücksichtigen, in welchem 's zum Object den durch Gott entstehenden Gluthwind erhält, so braucht der ältere Erzähler unser Verbum nur so, dafs die Geschöpfe, denen Gott einen Befehl zukommen lälst, nicht erst durch ihn ihr Dasein erlangen, um denselben auszuführen. $\mathrm{Zu}$ letzterem Zweck war jeder bereits vorhandene דג וימן und ju vede ist nicht ויבראה. Daraus folgt, dafs nach dem ursprünglichen Verfasser, auch der קיקויון, dem Gott einen Auftrag gab, damals schon bestand, wenn auch als niedrige Pflanze, und dafs derselbe nur (wohl in beliebiger, seiner Natur gemäls nicht allzulanger Zeit) für die Schattenspendung die Höhe eines Baumes erreichen sollte. Ein Wunder am Kikajon zu thun, ihn ebenso schnell wachsen wie welken zu lassen, hatte Gott keine Veranlassung; ihm kam es nur darauf an, das Mitleid des Propheten zu wecken, und dazu genügte es, dafs der Baum herrlich gedieh und unerwartet zerstört wurde. Also hat ein späterer Leser $10 \mathrm{~b}$ interpolirt; möglicherweise derselbe, der 8 a mit seinem כזרח השטש schrieb, eine Zeitangabe, welche, ebenso wie בעלות השמשר, nach Hitzigs Bemerkung nichts zur Sache thut und etwa an Gen. 19, 15. 23 erinnert. Die Vermuthung, dafs grade dieser Schriftsteller das überlieferte וימן .. falsch auffafste, liegt um so näher, als in 8 a dieses Verbum im Sinne von „entstehen lassen " ( oder "etwas eben Entstandenes herbeiführen " gebraucht ist. Nun wird es uns auch nicht mehr auffallen, dafs das, wie wir vorher sagten, an erster Stelle erwartete Argument an zweiter resp. dritter steht; es ist eben später in den 
Text gesetzt; vgl. 4, להיות וג' להציל וג' - Es lälst sich annehmen, dafs schon die älteste Quelle den durch einen Relativsatz genauer bestimmte; ob aber durch den vorliegenden, ist eine andere Frage. Die Worte משר לא עמלת בו sind offenbar zu Nineve der grofsen Stadt" 11 a in der Form אשר עמלתי בה לה hinzuzudenken und beziehen sich, losgelöst vom Folgenden, auf die Sorge, welche Jahve hatte, um die Bekehrung der Stadt zu ermöglichen und dadurch ihren Untergang zu verhindern. Die Berufung des Propheten aus fernem Lande sowie die Anstalten, die Jahve treffen mufste, um den Jona zu strafen und endlich sich gefügig zu machen, vielleicht auch die Reden, die er ihm in den Mund legte, werden hier als Zeugnisse für die Mühe Jahves um Nineve angesehen. Dafs er selbst dieses grols gemacht hatte, ist für die Beweisführung nicht durchaus nothwendig und liegt aul'serhalb unserer Erzählung. Daher glaube ich, dafs die Wendung ולא גהלתו von dem zweiten Schriftsteller, der, wie sich ergeben wird, den ersten gekannt hat, in seinen Parallelbericht eingefügt wurde als ein weiteres Argument für die Theilnahme des Gottes Israels an Nineves Geschick; ob er dabei das עמל ב Jahves in Bezug auf die Stadt als ein „sich mühen um die Grölse (statt : um die Bekehrung) derselben " deutete oder nicht, ist unwesentlich. - Demselben Autor vindicire ich $11 \mathrm{~b}$ aufser etwa den vorher besprochenen Schlufsworten. Für den originalen Verfasser reichte ein emphatisches נינוה העיר הגרולה aus, zu welcher Bezeichnung man אשר עמלתי בהרי (s. oben) ergänzen mochte; höchstens hat er, was mir aber nicht wahrscheinlich vorkommt; dieselbe durch einen Satz wie אשר יש בהיה אדם רב erweitert. - Im Relativsatz אשר לא ידע וג V. 11 ist mir wenigstens der Gebrauch des Singulars in ידע und den Suffixen von ישמאלו ישונו anstölsig; hat ein Versehen, z. B. die Auslassung des 1 hinter ידע, eine Correctur des Schlusses der anderen Worte (auf $\square_{\tau}$ ) veranlafst? - Das 
חרישית R. 8 ist nach Steiner vielleicht zu lesen, „welches als Ableitung von חרר Sonne ${ }_{n}$ heifs, glühend «" bedeuten könnte." Doch ist die Vertauschung des $\square$ mit it in nicht zu belegen und auch wenig glaublich, da hierdurch eine Verwechselung mit „Scherbe ${ }^{\star}$ und manchen andern Worten entstanden wäre; sodann würde in einem Ausdruck des alltäglichen Lebens die Verwendung des seltenen (ächten?) חרם statt des üb-

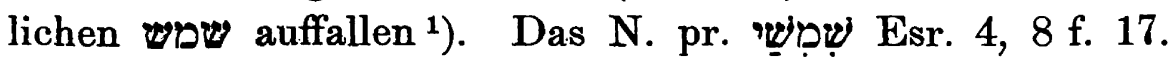
23, vielleicht einem Dialect entlehnt, kann „der Sonne geweiht ${ }^{*}$ bezeichnen; oder wäre es שִ zu lesen und als eine Entstellung aus שִׁ zu betrachten, wie möglicher-

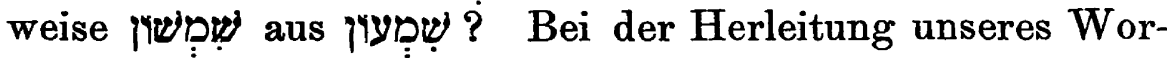
tes von sollte man ferner eher die Bedeutung , sonnig, von der Sonne beschienen" als gglühend" erwarten. Ein Verbum חרס „glựhen (Gesen. Lex. noch in der 9: Aufl.) ist wohl nur wegen חר „Sonne ${ }^{\alpha}$ angenommen. Unbeחriedigend ist aufserdem die Uebersetzung von חרישית durch "schweigend" (schwül), „betäubend, sausend", also

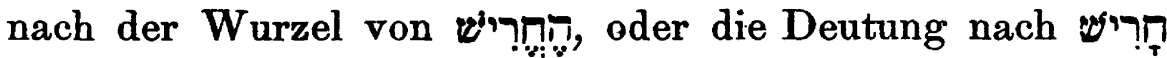
qualis flat tempore arandi. Gegen letzteres spricht sich auch Steiner aus; Bedenken erregen mufs der Umstand, dafs von den חָריר

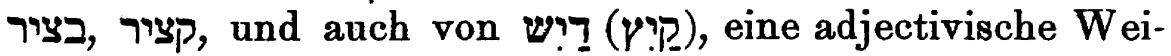
terbildung mit ? nicht vorhanden ist. Hitzig denkt sich als den Sinn des Adjectivs „herbstlich“, und Grätz a.a.O. S. 135 verlangt חריפית; doch sähe man hier lieber eine Beziehung auf die Sommerzeit. Stände es fest, dafs die

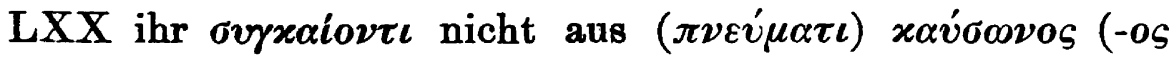
richtig Vollers) und der Wirkung des Windes gerathen

1) Die treffliche Emendation des überlieferten הרחา Richt. 14, 18

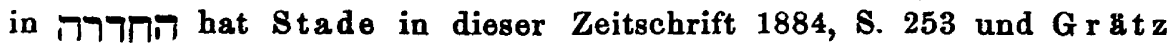
im Psalmencommentar Bd. 1 S. 143 veröffentlicht, dieser jedoch mit der abweichenden, nicht eu billigenden Punctation 
hätte, so wäre die Vermuthung nicht za gewagt, dafs sie חרר im giebt sie durch

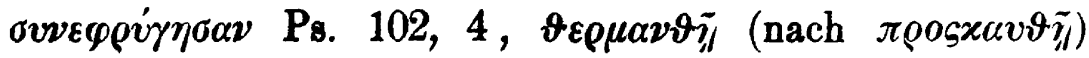
Ezech. 24, 11 ; auch Hiob 30, 30 fügt cod. Alex. a. E. ein

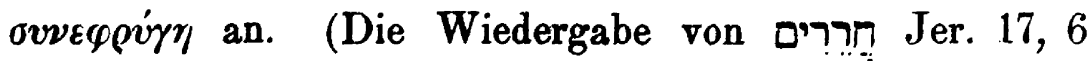
durch $\dot{\varepsilon} \nu$ à $\lambda i \mu o \iota s$ beruht wohl auf der Heranziehung des folgenden parallelen $\dot{\varepsilon} \boldsymbol{v} \gamma \tilde{y} \dot{\alpha} \lambda \mu v \rho \tilde{a}$.$) Hinsichtlich der For-$ mation darf man vergleichen מרירי Deut. 32, 24 und ערירי, beides von einem intransitiven Verb. med. ( ר) gemin. herstammend; ferner den, allerdings der Endung ?- entbehrenden Ausdruck צחיחים, צחיחה (צוזים, wie das Keri richtig liest statt צח Neh. 4, 7). Dals ein „unerträglich heifser" Wind gemeint sein mufs, ist auch Steiners Ansicht, der auf Gen. 41, 6. 23 (שרְפות קרים) verweist. Eine über allen Zweifel erhabene Erklärung oder Verbesserung von הרישית wird sich kaum geben lassen; nach Vollers

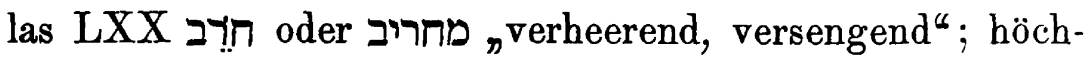
stens doch wohl חריבית, das aber stärker als das vorgeschlagene לירית von der Ueberlieferung abweicht. - Die

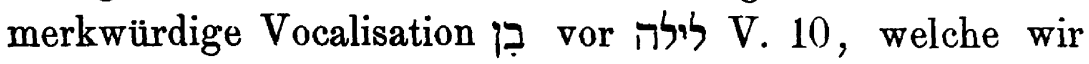

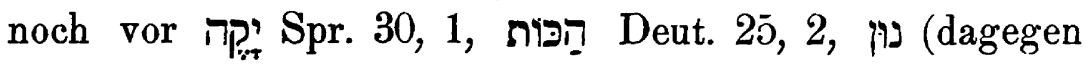
Hieronymus im prologus galeatus nincipiunt ab Hiesu filio Nave, qui apud eos Josue ben Nun dicitur") und in (בנימיני) antreffen, stellt wohl eine (spätere) dialektische Verschiedenheit gewisser Gegenden dar, welche in den Eigennamen בנימין allgemein durchdrang, sonst aber nur vereinzelt in den massoretischen Text eingeführt wurde. Endlich hat die Nichtübersetzung von אל אנר 4, 2 in der LXX so wenig wie manches Plus, das sie bietet, und wie eine Menge von Ungenauigkeiten und Verkehrtheiten ihrer Version in allen Capiteln irgendwelche Bedeutung für die Feststellung des originalen hebräischen Textes in unserem Buche.

Versuchen wir jetzt, indem wir vorläufig von dem eingefügten zusammenhängenden Liede in Cap. 2 absehen, 
den Antheil, welchen der Haupterzähler (A), der Bearbeiter eines Theiles von demselben Stoff (B), der Ergänzer (C) und der Redactor $(R)$ an der vorliegenden Schrift haben, noch genauer zu ermitteln, insbesondere an denjenigen Stellen, für deren richtige Beurtheilung es uns bisher noch an einem Anhaltspunkte gebrach. Wir verbinden damit, soweit das für unsern $Z$ weck erforderlich ist, die Angabe einiger Eigenthümlichkeiten der Schriftsteller in ihrer Darstellungs- und Redeweise.

Der von uns als A bezeichneten Grundlage des Buches Jona weisen wir zu 1, 1-5a mit unbedeutenden Auslassungen in 3 und $4 \mathrm{a} ; 7.8$ mit Ausnahme des Schlusses von $8 a$ und $8 b ; 9.10$ bis גדולה, 11-13, weniges ausgenommen; 15 (nicht 16). 2, 1. 11. 3, 1-3 a. 4 b. 5. 4, 1. 5 a (inhaltlich); 6 ohne die letzten Worte von $\left.6 a^{1}\right) ; 7$, ohne den Schlufs von 7 a. 8 b. 9. 10a (grölstentheils) 11 a. Eine erkennbare Lücke hat diese Erzählung durch R erhalten hinter 3, 5, wo A berichtet haben muls, dafs Gott um der Bufse der Nineviten willen ihre Stadt nicht zerstörte: 3, 10 nämlich ist aus $B$ aufgenommen, wie die mit

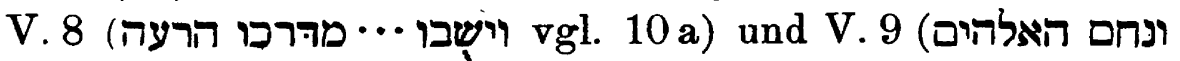
vgl. 'וינח (10 b) übereinstimmende Schilderung beweist. A hat sich in der entsprechenden Erzählung jedenfalls kürzer ausgedrückt und ist deshalb übergangen worden. Dafs und wodurch Jona die Aenderung des göttlichen Entschlusses in Betreff Nineves erfuhr, brauchte der Verfasser nicht anzugeben; sobald die vierzigtägige Frist verflossen war, konnte der Prophet an jener Wandelung nicht zweifeln. Ueber $3,3 \mathrm{~b}$ s. unsre Bemerkungen zu B. In 4, 5a wird יונה in A wohl nicht existirt haben, da der Vers sich an 4, 1 anschlofs; vielleicht stammt es dort aus $\mathrm{B}$, wenn der Redactor schon in $4,5 \mathrm{a}$ (nicht erst in $5 \mathrm{~b}$ )

1) Von dem Gebrauch der Gottesnamen bei den einzelnen Autoren wird später die Rede sein.

Zeitschrift f. d. alttest. Wiss. Jahrgang 7. 1887. 
den Bericht von $B$ reproducirte, in welchem, wie wir weiter unten auseinandersetzen werden, 3, 9 (aus dem Edict des Königs) dem Vers 4, 5 a voranging. In 4, 8 b fand sich in A (und B) hinter יונה wahrscheinlich noch welchen Namen der Interpolator als entbehrlich nach seinem Einsatz 8a wegliefs; zur Verknüpfung von וישאל $8 \mathrm{~b}$ mit 7 b vgl. 1 Kön. 19, 4 b nach 4 a. - Der Verfasser unserer Schrift, welche an Umfang ihre jetzige Vorgängerin, das Buch des sogenannten Obadja, übertrifft, dem des Haggai aber nicht gleichkommt, erzählt einfach und schmucklos (wie denn bei ihm nicht einmal ein Kürze ist bisweilen tadelnswerth. Zur Motivirung des ungewöhnlichen Befehles Jahves an Jona hinsichtlich der רעה Nineviten genügt ihm כי עלתה רעתם לפני derselben bestand, weshalb Jona flieht, was er auf die Frage פה-פלאכתך geantwortet, erfahren wir durch A nicht. Man mag es entschuldigen, dafs der Erzähler, etwa um den Eindruck der letzten Aeufserung Jahves durch nichts abzuschwächen, uns das beschämende Schuldgeständnifs des Propheten am Schlufs des Buches vorenthalten hat; aber dafs letzterer nach seiner doppelten Errettung 2, 11 nicht einmal ein Wort des Dankes an Jahre hat, ist in hohem Grade auffällig. Hitzig findet es verkehrt, dafs Jona (nach diesem Darsteller, setze ich hinzu) die Entscheidung über das Schicksal der Stadt im Bereiche derselben abwartete; doch hat der Autor, wenn ihm überhaupt der Gedanke daran kam, wahrscheinlich gemeint, dafs Jahve schon Mittel und Wege gefunden haben würde, bei der allgemeinen Vernichtung seinen Propheten unversehrt hinauszuführen; wie leicht konnte er ihm am Ende der bestimmten Zeit einen Wink geben, dafs er Nineve verlassen möge! Die Reden der handelnden Personen beschränkt A auf das geringste Mafs. Die Predigt des Jona, an welcher Jahve so viel liegt, die der Prophet, von ihm inspirirt, hält, und deren ungeahnter Erfolg die Bekehrung 
der grofsen, heidnischen, in Laster versunkenen Stadt ist, konnte nicht knapper wiedergegeben werden als wir in 3, 4 b lesen. Ist es da glaublich, dafs derselbe Schriftsteller, der an einem Wendepunkte seiner Geschichte zu einer durch die Sachlage fast gebotenen Ausführlichkeit (Hinweis auf die Sündhaftigkeit des Volkes, auf die Macht und die Wahrhaftigkeit des verkündeten Gottes, auf die Schrecken des Unterganges) sich nicht aufzuschwingen vermocht hat - dafs derselbe Schriftsteller bei weniger wichtigen Anlässen, z. B. 1, 14 und 4, 2 f., die dort auftretenden Personen sich lebhaft und wortreich aussprechen liefs? Man stelle neben diese Verse die directen Reden in 1, 2. 3, 2. 1, 12, die längsten, die erweislich von ihm herrühren, und man wird mir nicht verdenken, dafs ich von der Ueberlieferung in 4, $10 \mathrm{f}$. für A nur wenig in Anspruch nehme. Charakteristisch ftur seine Diction ist der Mangel an Conjunctionen aufser, und כי. Einen indirecten Fragesatz finden wir 1, 7. Mit dem nur als Relativ gebrauchten 1, 7. 1, 12. Einige Verba verbindet er mit gleichstämmiוירע gen Substantiven, nämlich ירא 1, 10 (nicht 1, 16 4, 1. שמח 4, 6; die letzteren bekommen dann das bei ihm beliebte Adjectiv (ה) גרול; man vgl. noch 1, 4.12. 2, 1 (3, 5) und das Attribut von העריר. Ueber und dessen Construction habe ich zu 4, 8 und 4, 10 gehandelt; begegnet uns 1, 4. 5. 12.15. Im Unterschied von B setzt A, wie wir oben sahen, לכשוח העיר 3,5; übei שים היה:רולה werden wir bei $B$ reden.

Die zweite Quelle B enthielt sicher die Verse 3, 6-10, in denen ich הפקר והצצאן 7 b, auch אל-ירעו 7 als Zusätze zu betrachten geneigt bin. Aufserdem schreibe ich $B$ den mit A unvereinbaren Halbvers 4, 5 b zu, aber nicht diese Stücke allein. Schon aus den aufgezählten Fragmenten erhellt, dafs ihr Urheber den von A bearbeiteten Stoff einer genaueren 
Behandlung, wenigstens zum Theil, unterzog. Hierbei legt er, worauf man bereits aufmerksam gemacht hat, durch seine Annahme eines Königs von Nineve (נינה vertritt nicht zugleich wie בבל die Provinz und das Reich) eine Unkenntnifs der geschichtlichen Verhältnisse an den Tag; ferner verräth seine Darlegung in 3,6ff. eine ausgeprägte ascetische Richtung, die wir in A nicht zu erkennen vermögen. In A hören wir in wenig Worten von der freiwilligen Bufse eines ganzen Volkes (Grols und Klein), von dem Ausrufen eines Fastens (natürlich des in Israel üblichen, daher keine Detailangabe) und von der Anlegung der Trauerkleider; $B$ dagegen referirt eingehend die Initiative des Königs in der Bekehrung und dazu seine gründliche Belehrung an sein Volk, wie Gott (durch das Verhalten von Mensch und Thier) etwa versöhnt werden könne, wozu auch das laute Rufen zu demselben gehört. Dafs uns die Befolgung der königlichen Anordnungen durch die Einwohnerschaft nicht ausdrücklich mitgetheilt wird, so dafs wir sie erst aus 3, 10 כי שבו u. s. w. erschliefsen müssen, ist ein Mangel in der Darstellung, welchen wir B nicht schlimm anrechnen wollen; oder hat er etwa eine Angabe darüber gebracht, $R$ aber, weil er das Thun der Nineviten bereits nach $\mathrm{A}$ in 3,5 berichtet hatte, die Parallelerzählung in seiner zweiten Vorlage auslassen zu dürfen geglaubt? Die Wendung 3,5 in A, von einem heidnischen Volke gebraucht, das Gott erst kennen lernt und trotzdem ihm $\pi i \sigma \tau \iota \varsigma$ entgegenbringt, ist übrigens treffender als die Phrase שוב אל האלהים in B, die allerdings in Israel die Rückkehr zu dem Gott zu bezeichnen pflegte, von dem man eine Zeit lang abgefallen war. - Nach B entfernt sich Jona aus der Stadt vor ihrer Zerstörung. Wahrscheinlich liefs der Verfasser ihn dies nicht aus dem Grunde thun, um sich nicht der Gefahr des Unterganges in und mit derselben auszusetzen (im Dienste Gottes hatte ja der, in der Tiefe so wunderbar erhaltene Prophet nichts zu befürchten); viel- 
mehr mochte er ein längeres Verweilen des Jona an einem Orte, dessen Bevölkerung mit der Umkehr vom Bösen vollen Ernst machte, nachdem der König (ohne den Jona zu fragen) die Sache selbst in die Hand genommen hatte, für zwecklos erachten. In A rechnet der Prophet mit Bestimmtheit auf die Vernichtung Nineves und sieht sich zu seinem grofsen Leidwesen enttäuscht, als dieselbe am 40 sten Tage nicht eingetreten ist (weshalb er hier frühestens am 41 sten aus der Stadt herausgeht). In B dagegen wird er, ebenso wie schon der König (in dem zum Theil aus Joel entlehnten Citat 3,9) die Möglichkeit einer Verschonung angedeutet hat, bei dem Anblick des Bufse thuenden Volkes selbst von Zweifel ergriffen, ob Gott in diesem aufserordentlichen Falle noch bei seinem Entschlusse beharren werde; daher seine Neugier zu erfahren מה-יהיה בעיר (ob

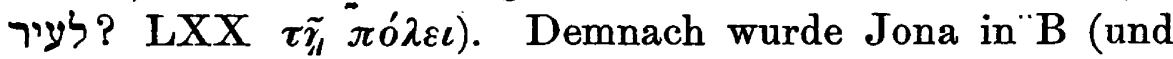
mit ihm der Leser, welcher nur diese Schrift kannte) von der Wendung der Dinge weniger überrascht als in A, und das ist kein Vortheil für die Erzählung. A verlegte den Vorgang mit dem קיקיון wohl in eine Gegend, in welcher der Prophet von Nineve nichts mehr sehen konnte und wollte, da die Betrachtung der Stadt immer auf's Neue seinen Verdrufs erregen mufste (מקרם לעיר 4, 5 a zu A ?); in B, wo von einer weiteren Ortsveränderung nicht gesprochen wird, wächst der Baum an einem Platze, von dem aus sich Nineve übersehen läfst (לראות 4,5 b). In der letztgenannten Quelle erbaut sich Jona zur Zeit, wo die Entscheidung über das Schicksal der Bewohner noch aussteht, ein Schirmdach, unter dem er natürlich auch später bleibt; in $\mathbf{A}$ ist er, nachdem er im Unmuth von Nineve geschieden, gleichgültig gegen seinen Aufenthaltsort (das freie Feld), wenn er nur die Stadt nicht schaut, gleichgültig auch gegen seine Gesundheit, so dafs sich Gott nur seiner annehmen und ihm durch den schnell emporwachsenden Baum Schutz gegen die Sonne schaffen mufs. So ist das Gewächs für 
ihn nicht nur ein Gegenstand der Betrachtung wie in B (wo ja auch Nineve dies später für ihn wird), sondern es bringt ihm auch wesentlichen Nutzen. - Absichtlich habe ich diese Differenzen zwischen $A$ und $B$ ausführlich behandelt, um zu zeigen, dafs die Erzählung in B einmal reicher an Detail, andererseits mebr durch Reflexion bestimmt ist als die in A; für die Ermittelung des aufserdem zu B Gehörigen ist jene Beobachtung von Belang. Den Grund dafür, dafs wir genauere Angaben über den Umfang von Nineve nicht schon in Cap. 1, sondern erst 3, 3 erhalten, hat man bisher wohl darin gesucht, dafs jetzt erst die Ausdehnung der Stadt für die zu erzählende Geschichte Bedeutung gewinne. Allein man übersehe nicht, dafs für das Verständnifs der im (Vorhergehenden oder) Folgenden berichteten Hauptthatsachen die antiquarische, übertreibende Bemerkung über die Gröfse der Riesenstadt keineswegs unerläfslich, dafs aber die Notiz über den Standort, welchen Jona bei seiner Predigt einnahm, vollends unwichtig ist. Die Quelle A mag, wenn sie den Eintritt des Propheten in die Stadt wirklich berichtete und nicht dem Leser eine darauf bezügliche Frgänzung hinter 3, 3 a überliefs, dies in einfacher Weise etwa mit den Worten gethan haben ויבא (יונה) בעיר (oder (בנינוה), denn das folgende

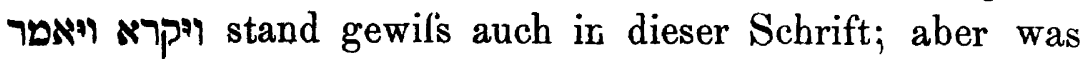
wir in 3,3b und 4 a antreffen (zu מהלך יום אחר vergleicht Hitzig S. 174 l Kön. 19, 4), ist Eigenthum des B, der sichtlich bemüht war, Trockenheit in seiner Darstellung zu vermeiden. Dabei giebt er sich in seiner Mittheilung über den Umfang der altberühmten Hauptstadt des assyrischen Reiches wahrscheinlich ebenso seiner Phantasie hin wie hinsichtlich des „Königs von Nineve. Phrase (וישב) מקדם לעיך 4, 5 nach ihrem Wortlaut schon in A habe ich vorher als etwas unsicher bezeichnet; anzunehmen ist sie wenigstens für $\mathrm{B}$, da das in $5 \mathrm{~b}$ begegnende שם auf die vorausgegangene Nennung eines Ortes 
in dieser Quelle hinweist. - Am Ende seines Commentars äufsert sich Hitzig: „Die Zahlangabe, welche die Gesammtbevölkerung Nineves zu einer ganz übermärsigen Höhe hinauftreibt, steht mit der Uebertreibung der Grölse 3, 3, wo das Mals des Umfanges dem Durchmesser zugetheilt wird, etwa noch im Verhältnifs." Anders Nöldeke, die alttestamentliche Literatur S. 74 : „nach dem ganzen Zusammenhange kann dies" (der Bericht in 3, 3 b) „nur bedeuten, dafs von einem Ende Nineve's bis zum andern mindestens 12 Meilen Wegs gewesen, so dals demnach die am Ende angeführte $Z$ ahl von mehr als 120000 unmündigen Kindern . . f für eine solche Grölse der Stadt noch viel zu gering, wäre, so bedeutend die daraus zu schliefsende Einwohnerzahl auch an und für sich schon sein mufs. * Wie dem auch sein mag, ich glaube nicht zu irren, wenn ich auch in 4, 11tb mindestens bis לשמאלו einen..Passus von B erblicke; seine Neigung zur Uebertreibung beweist der Schriftsteller ja auch in seinen Vorschriften wegen des Fastens in 3, 7. Seinem Büchlein ist vermuthlich der Relativsatz 4, 10a entnommen; denn wenn auch (עיר) גרולה לאלהים (eine Stadt) grols durch

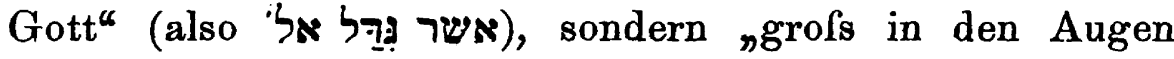
Gottes" bezeichnen mag, so hat die dortige Parenthese doch nur dann einen Sinn, wenn sie hervorheben soll, dafs Gott sich um Nineve kümmerte, und vielleicht auch, weshalb ihm an der Bekehrung desselben gelegen war; immerhin tritt die Zusammenstellung von Gott, Nineve und dem Begriff „grofs" (deutlich in 3, $3 \mathrm{~b}$, implicite in $4,11 \mathrm{~b}$ nach 10 a vorhanden) nur an diesen beiden Stellen des Jonabuches auf. - Bereits oben deuteten wir an, dafs B aufser den hier besprochenen Stücken die Aufforderung Gottes an Jona (parallel zu 3, 1-3a), die Predigt des letzteren (ähnlich 3, 4 b), den Unmuth des Propheten über die Verschonung der Stadt (ähnlich 4,1), diesen aber erst hinter 4, 5 und nach der Mittheilung, dafs Jona die Nicht- 
erfüllung seiner Weissagung (an Gottes Verfahren) erkannte, dargestellt hat. Ebenso wurde in dieser Quelle das Wachsen und Verdorren des Baumes, die Freude und Betrübnifs des Propheten hierüber und die Verhandlung Gottes mit ihm beschrieben. Der Wortlaut der von E wegen des mit $\mathbf{A}$ übereinstimmenden Inhalts übergangenen Partieen von $B$ läfst sich selbstverständlich nicht angeben; allzugrofs wird indessen die Discrepanz zwischen beiden Schriften hierin nicht gewesen sein. Aus 3, 6-9 (10) erhellt, dafs B kein ungewandter Schriftsteller war (vgl. auch 4, 10 f.); da nun $R$ durch die Aufnahme jener Verse bewiesen hat, dafs er durchaus nicht auf Verkürzung der Ueberlieferung ausging, so würde er wahrscheinlich, wenn nicht überall, so doch hier und da eine im Verhältnifs zu A ausführlichere und stilistisch bessere Fassung von B sich angeeignet haben, wenn eine solche ihm vorgelegen hätte, vor allem an der durch ihre Kürze anstöfsigen Stelle 3, 4 b. Mit A contrastirt B durch die Ausschmückung des Stoffes in 3, 6-9, durch die Breite der Ausdrucksweise in 3, 10; wie umständlich lautet, um nur dies Eine noch zu erwähnen, in derselben Sache die Schilderung 3, 6 mit

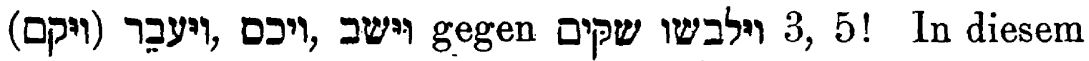
Punkte darf man die, das einfache העיר הגדולה (A) erläu-

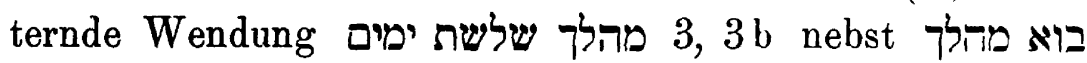
(אשר יש-בהי) הרבה משתים עשרה רבפו ארם 3,4a, dazu יום אחד יפום 4, 11 nicht gleichstellen den für den Zusammenhang fast unentbehrlichen, formelhaft klingenden Zahlangaben in A 2, 1 und (wahrscheinlich auch von B acceptirt) ארבעים יום 3, 4 b (vgl. 1 Kön. 19, 8). - In der Phraseologie unterscheidet sich $B$ von A durch den

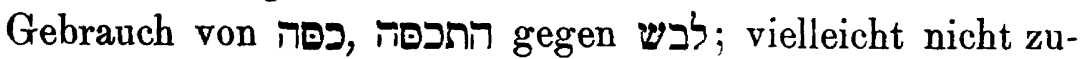

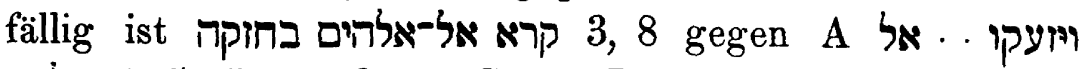
1,5 (im anderen Sinne B אלהיו 3, 3, 7) und das gebräuchlichere שלשת יםים 3,5 (B) in kurzer Entfernung von שלשה ימים gesetzt, welches aufser Jon. 2, 1 (A) im 
A. T. nur noch 1 Sam. 30, 12. 1 Kön. 12, 5. 2 Kön. 2, 17 gefunden wird. In den uns erhaltenen Fragmenten von B treffen wir nie שֶׁ, sondern nur 3.8.10 (4,10 wohl nach A) 4, 11 an, und, abgesehen von I und כי, wenigstens noch die Conjunction 4 4 4,5 und ebendort einen indirecten Fragesatz; über 3י מיודער s. später. Der Gedanke an eine Benutzung von $B$ durch $A$ ist von vornherein ausgeschlossen; der Verf. der letzteren Schrift müfste eine Art Auszug aus B geliefert und dabei doch wieder manche Veränderungen vorgenommen haben, deren Grund sich nicht einsehen läfst. Auch die Annahme eines gemeinsamen Ursprungs beider Berichte würde nirgends eine Stütze finden; einen litterarischen Vorgänger hat A so wenig in Cap. 3 und 4 wie in 1 und 2 gehabt. Dagegen spricht alles dafür, dafs A von B gekannt und umgewandelt wurde. - Dem B erschien die Bufse der Nineviten, wie A sie darstellte, nicht gründlich und systematisch genug (hat auf die Einführung des Königs etwa auch מגרולם in A Einfluf's gehabt?), ein längerer Aufenthalt des Propheten in der sich auf's Schnellste bekehrenden Stadt überflüssig (während er in $A$ auf seinem Posten ausharrt), der Bau einer Hütte, nachdem er sich von Nineve früh entfernt, unumgänglich nothwendig (war er doch keineswegs verdriefslich, sondern in lebhafter Spannung wegen des Ausgangs der Sache, als er auf das freie Feld sich begab). Hinsichtlich des Namens נינוה mag B sich anfangs nach $A$, von welchem 3,2 . 3 a. 4 b. 5 herrühren, gerichtet haben, vgl. 3, $6.7(4,11=\mathrm{A})$; allein nachdem er schon in 3, $3 \mathrm{~b}$ das ihm aus $\mathrm{A}$ bekannte עאלהים durch erweitert, braucht er in 3,4a בעיר, und sicher dasselbe Substantiv 4, 5a. Ob A, der yיר wenigstens in der, wahrscheinlich stets ohne Zusatz bei ihm vorkommenden Formel רעיר (1, 2. 3, 2. 4, 11) verwandte, auch in 4, 5 a resp. in seiner Parallelerzählung נינות geschrieben hat, ist nicht auszumachen. - So deutlich also 
die Quelle B in den letzten Capp. unseres Buches zu Tage tritt, so wenig sind Spuren derselben in den beiden ersten zu entdecken, weshalb das שon A 3,1 in B nicht gestanden haben kann.

Im Laufe der Untersuchung trat uns eine interessante sachliche Aehnlichkeit zwischen 4, 2 f. und 1, 14 entgegen. An beiden Orten legt der Schriftsteller den Personen Reden oder vielmehr Klagen vor Jahve in den Mund, an beiden aber versieht er sich in der Angabe des Motivs, welches sie bei ihrer Bitte leitet $(1,14$ von ואל- an) oder bei ihrem früheren Thun geleitet hat (4, 2'כי ירעתי וג'ואחי). Sprachlich beachtenswerth ist beide Male die Formel אָָּ יהוה; dazu kommt, dafs nur diese Stellen des A. T. die Schreibung der Partikel mit Schlufs-in, unter Verkennung ihres Ursprungs ${ }^{1}$ ), darbieten; wir werden daher die Identität des Schreibenden in jenen Versen nicht bezweifeln dürfen. Wie zum Theil in 1, 14, so leiht der Erzähler auch in 1, 10 der Furcht der Schiffer Worte, wobei er das im originalen Bericht Versäumte ( $\mathrm{ggl}$ zu 4, 2 f.) nach-

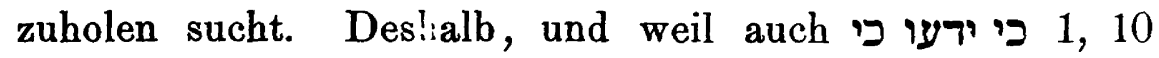
mit מי 1,12 A) zusammentrifft,

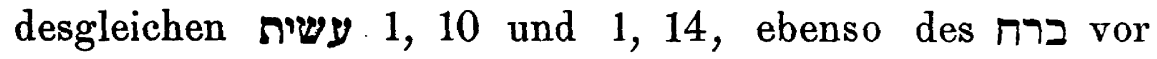
Jahve in 1, 10 wie in 4, 2 gedacht wird, schreibe ich 1, 10 von $i$ an demselben Autor zu ${ }^{2}$ ). Nicht minder ver-

1) Diesen findet man gewöhnlich (auch Stade, hebr. Gr. § 373)

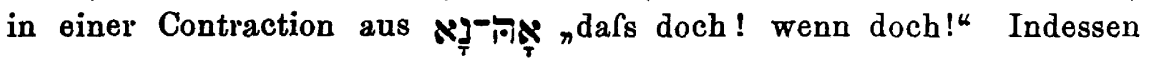

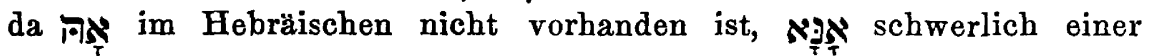
alten Zeit der Sprache angehört und selbst eine Verbindung von Pִ mit $\aleph_{\text {J }}$, an die man otwa denken könnte, sich nicht nachweisen lälst,

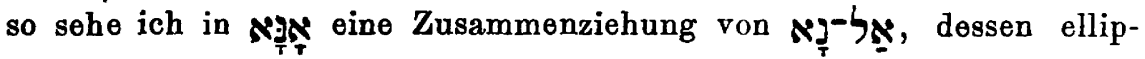
tischer Gebrauch in der Rede des täglichen Lebens später verkannt wurde, so dals einer Verderbnifs der Formel durch Assimilation des $\}$ an 3 nichts im Wege stand.

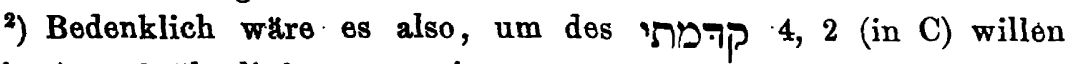
das in A 1, 3 überlieferte ויקרם zu ändern. 
danken wir ihm 1, $5 \mathrm{~b}$ f., welches wir oben $A$ abgesprochen

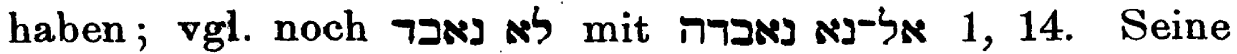
Vorliebe für Reden und Reminiscenzen bewegt ihn offenbar, die Aeufserung des Jona 4, 8 b nach 1 Kön. 19, 4 b zu erweitern und umzubilden, und dann schon in 4, 3 einzusetzen, wodurch sie bei ihrer Wiederholung in kürzerer Form an ihrem ursprünglichen Orte $4,8 \mathrm{~b}$ an Wirksamkeit verliert. In der älteren Schrift $A$ (und auch in B) war das 4, 4, 8 b nicht gleichbedeutend mit 4, 1 'וירע, wozu es erst $\mathrm{C}$ durch 4, 3 hat machen wollen, sondern eine naturgemälse Steigerung des vorher gesetzten Ausdrucks ${ }^{1}$ ). Von A verschieden, ist dieser „Ergänzer“, wie ich ihn oben nannte, doch nicht gleich B. Ein oberflächlicher Blick wird zwar in 4, 2 dieselbe Hand vermuthen, welche 3, 10 ויפחם האל' על עלתר schrieb; allein die Vergleichung von 1, 6 אולי יתעשת האל' ergiebt מי יורע . . . ונחם האל' נלא נאבר mit 3, mit höchster Wahrscheinlichkeit, dafs der Darsteller in 1,

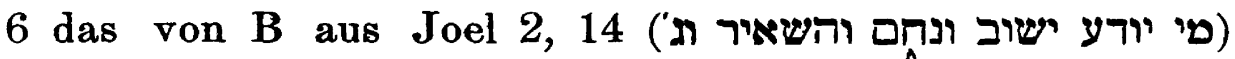
aufgenommene מי מיר teren und das bei der Situation in 1, 6 nicht verwendbare החת vertauschte. Die Abhängigkeit der letzteren Stelle von 3, 9 zeigt sich auch darin, dafs, während hier im Context richtig האלהים steht, d. h. der den Nineviten gepredigte und nunmehr bekannte Gott ${ }^{2}$ ), in 1,6 dafür אלהיך gesetzt sein mürste, da ja der Capitän den Gott des Jona, den wahren Gott und Urheber des Sturms (und das ist doch ראלהים), nicht kennt. So fällt der Verfasser, der יהוה noch nicht schreiben will und kann

1) Auf die eingefügten Reden folgt keine Antwort der angeredeten Personen 1, 6 (hat Jona nach dem Autor gebetet oder nicht?) 1, 14. 4, 2.

2) Ueber die Setzang von Elohim an dieser Stelle in B werden wir das Genauere spüter mittheilen. 
(anders in 1,10b und 1, 14), mit seinem אלהיך (אידהים ging schon vorher und liefs sich durch passend ersetzen) einigermafsen aus der Rolle. Dafs der Autor in gleicher Weise wie B 3, $9(4,5$ b) die Möglichkeit einer Rettung andeutet, ist kein Vorzug seiner Erzählung vor der $\operatorname{des}$ A, bei welchem wir die Schiffer, als neben oder nach dem Beten die Entlastung des Fahrzeugs nichts geholfen hat, zum äufsersten Mittel, dem Loose, greifen sehen und selbst ihre Erwartung theilen, ob hierdurch der Schuldige entdeckt werden und was dann mit ihm geschehen wird um den Untergang abzuwenden $(1,6)$. (Die ursprüngliche Schrift, mit Reden so karg, läfst hier, in der höchsten Noth, die Schiffsmannschaft zu ersten Mal in Worten sich äufsern.) - Der von B berücksichtigte Prophet Joel ist auch unserm Ergänzer sehr wohl bekannt. Nur Joel 2, 13 und Jon. 4, 2 begegnen wir dem Part. Niph. נחם mit ?, welchem על מל-הרעה mit andern Attributen vקיא Auch die Gleichheit in der Schreibungeht. Jon. 1, 14 und Joel 4, 19 ist schwerlich auf den Zufall, denselben Abschreiber u. ä. zurückzuführen. Aehnlich nun wie $\mathrm{C}$ den Vers 4, 3 nach 4,8 b (A) und mit Benutzung des daselbst verwendeten Verses 1 Kön. 19, 4 umgestaltete, läfst er sich in 4, 2 durch '3חם החל 3,9 und 3,10 bestimmen, den Vers, welchen wir unmittelbar vor der, dem B vorschwebenden Stelle des Joel antreffen, zur Hälfte auszuschreiben, ja Jona mufs bei ihm seine angebliche Kenntnifs der in dem andern Propheten 2, 13 (freilich auch sonst ähnlich) erwähnten Gesinnung Jahves als den Beweggrund zu seiner, der Rechtfertigung so sehr bedürfenden Flucht anführen. - $\mathrm{Ob}$ die Veranlassung zur Einführung des רבו-החל 1, 6 neben den Seeleuten unserm Schriftsteller etwa durch die Erzählung vom עלך נינוה neben den Nineviten in B gegeben wurde, ist weniger sicher; vgl. das oben zu 1, 6 Bemerkte. - Die mit einer Erweiterung verbundene Anwendung von 
1, 10 im ersten Halbvers von 1, 16 und die vorgreifende von 2, 10 im zweiten Gliede eben jenes Verses kann uns nur in dem schon ausgesprochenen Verdacht bestärken, dafs der ganze Satz erst von C eingefügt wurde, der möglicherweise auch 1, $8 \mathrm{~b}$ von מה an, aber wohl kaum Einiges in 1,12 und den überflüssigen Passus von ויהי bis zum Athnach in 1, 4 verfafst hat. Später als $\mathrm{C}$ möchte ich 1, 16 nicht ansetzen, da schon früh ein Leser eine Angabe darüber, welchen Eindruck die Vorgänge mit Jona auf die Schiffer gemacht haben, im Text vermissen und schon der erste Erweiterer von $A$ in Cap. 1 überzeugt sein mochte, dafs die heidnischen Seeleute, nachdem sie Jahve kennen gelernt, in der Verehrung desselben hinter den Nineviten und hinter Jona $(2,10)$ selbst nicht zurückstanden. - Unsere bisherigen Ermittelungen über $\mathrm{C}$ reichen bereits hin, um uns in demselben einen lebhaften, redegewandten (vgl. B 3,7 ff.), mit der Litteratur vertrauten Autor erblicken zu lassen, der bisweilen im engeren Anschlufs an das Original seiner Vorgänger schrieb, als diese selbst es für nöthig hielten, und der den ihm noch zu dürr und dürftig erscheinenden Text der Ueberlieferung durch erklärende und ausschmückende Zugaben, freilich nicht in der rechten Art, zu verbessern, insbesondere den in seinen Quellen nur kurz berichteten Gefühlen der Furcht und des Unmuths durch Worte Ausdruck zu geben beflissen war. Kein Wunder daher, dafs uns bei C von Partikeln aufser , כי כ" כweimal in 4, 2 nach A 1, 12; dreimal 1, 10; 1 ; 14. 4,2) nicht nur 1,14 und על-2, 2, sondern auch

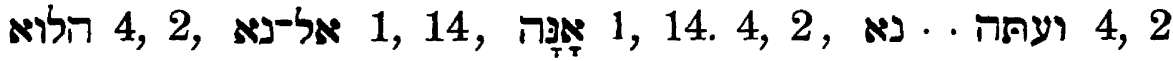
(1 Kön. 19, 4 nur עתה ) begegnen. (Die sprachliche Differenz zwischen $C$ und $A$ in אניה 1, 1 מפינה ist schon früher berührt.)

Nicht nur zur Bestätigung der gewonnenen Resultate, sondern auch zur Erforschung weiterer Details, die für die Entstehungsgeschichte unseres Buches von Werth sind, 
soll uns die folgende Betrachtung über die Verschiedenheit der Gottesnamen dienen. Natürlich nehme ich von derselben diejenigen Stellen aus, an denen אלהים im stat. constr. $(1,9)$ oder mit einem Suffix $(1,5 ;$ auch 2, 2. 7) vorkommt. Ich beginne mit Hitzig's Bemerkung zu 3, 10 : „In Beziehung tretend $z u$ den Heiden heifst Gott seit V. 5 (vgl. 1, 6) אלהים; 4, 2 tritt der Eigenname wieder ein." Diese Angabe könnte uns schon befriedigen, wenn nur nicht 4, 7 (8 im Zusatz) 9 der Name Elohim aufs neue erschiene, und zwar in einem Zusammenhange, in welchem Gott mit Jona allein zu thun hat. Hitzig bringt auch hierfür sowie für das singuläre, äufserst befremdliche הודי 4, 6 einen Grund bei in der Note : ${ }_{n}$ Nachdem bereits im 4. V. die Reminiscenz des Vf. auf den Anfang der Genesis gerathen ist" (ich habe mich im Vorhergehenden gegen die Zuweisung dieses Verses an $\mathrm{C}$ ausgespro. chen), entlehnt er hier aus 1 Mos. 2, 4-3, 24 die Verbindung יהוה אלהים, wofür dann V. 7-9 wie 1 Mos. 3, 1. 3 blos אלהים." Die richtige Ansicht, dafs in den zuletzt genannten Versen der Genesis kein willkürlicher Wechsel vorliegt, sondern ,im Munde des Thieres der heiligste Name Jahve absichtlich vermieden ist" (Dillmann im Commentar), herrscht jetzt wohl allgemein; hinsichtlich des Uebrigen, was Hitzig a. a. O. geäusert, halte ich mich der Zustimmung der Mitforscher versichert, wenn ich es als eine starke Verirrung des leider oft mit seinem Scharfsinn über das Ziel hinausschiefsenden Kritikers ansehe und jede Polemik dagegen unterlasse. Dem nachdenkenden Leser aber, der von den beiden ersten Capiteln des Buches Jona zu den letzten (genauer, zu 3, $3 \mathrm{~b}$ und dem Folgenden) gelangt, wird sich, wenn er Hitzig's Auslegung mit mir zurückweist, um so mehr die Nothwendigkeit aufdrängen, für den Wechsel der Gottesbezeichnungen in Cap. 3 und 4, welcher unmöglich auf eine Laune des oder der Schriftsteller oder gar auf die oscitantia librariorum 
zurückgeht, eine ausreichende Erklärung zu suchen. Nirgends verlangt man dieselbe mehr als im Schlufscapitel, wo in bunter Folge (ich setze die nicht von $A, B$ oder $C$ herrührenden Verse oder Verstheile in Klammern) sich יהוה

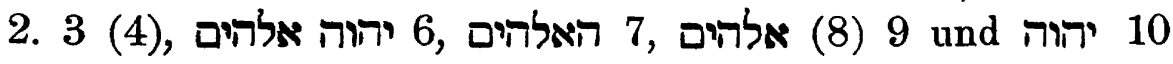
bewegen, und sogar innerhalb derselben Verhandlung (9f.) die Gottheit zuerst ' $\$$ ', dann ' $ה$ ' heifst. Zur Erkenntnifs des Sachverhalts sei zunächst darauf hingewiesen, dafs C aufser in 1,6, worüber schon geredet ist, durchweg des Namens Jahve sich bedient, so 1, 10 in dem Referat des von Jona den Schiffern Erzählten, 1, 14 im Gebet derselben sowie in der Einleitung dazu (1, 16, wo die Furcht vor Jahve und das Opfer für ihn berichtet wird), 4, 2 f. in der Klage des Propheten und in 'ויתפלל אל-יה. Die Verse 3, 8-10 sind also nicht aus der Feder dieses Darstellers geflossen; denn da er weder in der Nähe von Nineve $(4,2)$ noch in der Rede der mit Jahve bekannt gewordenen Heiden (1, 14; vgl. 1, 16) das heilige Wort zu brauchen sich scheut, so würde er, zumal nachdem er in $3,2 \mathrm{~b}$ ausdrücklich Jahve als den Urheber der Verkündigung an die Nineviten gefunden hatte, gewifs im Munde des Königs V. $8 \mathrm{f}$, unter allen Umständen aber V. $10 \mathrm{im}$ historischen Bericht den speciellen Gottesnamen verwendet haben. Die Abkunft dieser Verse von $B$ ist oben dargelegt worden; hier gerathen wir wohl auf die Vermuthung, B möchte aus irgendwelchem Grunde die Bezeichnung Elohim vorgezogen haben, und darin irren wir uns in der That nicht. A sagt durchweg Jahve in den von ihm herkommenden Abschnitten in 1, 1-3, 3a; später zeigt sich das $N$. pr. nur noch 4, 10, in einer Angabe, von welcher ein Theil zweifellos in A existirt hat. Die enge Verbindung von 4, 10 mit 4, 9 läfst uns für den Bericht dieser Quelle auch in letzterem Verse Jahve voraussetzen, und warum sollte dann in 4, 7.6 und in der ausgelassenen Parallelerzählung zu 3, 10 der Schriftsteller von seiner Gewohnheit abge- 
wichen sein? In 4, 7.9 ist demnach Elohim vom Redactor nach $B$ gesetzt, welches eine wesentlich gleiche Relation mit A enthielt und wenigstens durch die Aufnahme des bei ihm üblichen Gottesnamens Berücksichtigung finden sollte. Selbstverständlich hat $\mathrm{R}$ auch 4,10 bei $\mathrm{B}$ dieses Wort gefunden, dennoch aber - mit Sicherheit vermögen wir sein Motiv nicht anzugeben - den heiligen Namen aus A gewählt. In 4, 6, wo er von B (5 b) zu A (יis יה' אל' לה (צל על־ראשו verfallen, bei welcher Jeder sich an das Verhältnifs von Gen. 1-2, $3 \mathrm{zu} \mathrm{2,} 4 \mathrm{ff}$. erinnern wird, wo ja der gleiche Uebergang von der Elohim- zur Jahvequelle stattfindet; eine Fortsetzung dieser Doppelbenennung hat ihm aber, im Gegensatz zu dem Redactor der Genesis, nicht beliebt. Zur Hand nahm der Vereiniger beider Schriften seine zweite Vorlage B wahrscheinlich erst in $3,3 \mathrm{~b}$; so begreift es sich, dafs er in 3, $1-3 \mathrm{a}$, wo die Parallele gewifs Elohim bot, das Jahve des A unverändert liefs. In $3,3 \mathrm{~b}$ aber ist der Gebrauch von Elohim durch die Sitte des B klar begründet; לאלהים bedeutet nicht, (grofs) in den Augen (selbst) der Gottheit", ist auch nicht deshalb eingetreten, weil der Erzähler sich plötzlich darauf besann, dals es unangemessen sei, während der Prophet auf dem Wege nach Nineve sich befinde, noch den heiligsten Namen Israels anzuwenden; endlich ist es nicht als Schreibfehler zu betrachten. Wenn das Targum hier „vor Jahve* sagt, so hat es wenigstens richtig gefühlt, dals nach den Worten נינוה העיר הגרולה im Munde Jahves 3, 2 (ebenso 1, 2. 4, 11) im parenthetischen Satze ein (Nineve) עיר גרולה לאלהים" seltsam berührt. In 3,10 , wo $R$ aufser der ausführlichen Darstellung von $B$ eine kürzere von A mit Jahve als Gottesnamen besafs, ist ihm eine Rücksichtnahme auf diese Bezeichnung nicht geboten erschienen, wenn er überhaupt bei dem Abschreiben eines längeren Bruchstücks von B jenes für ihn geringfügigen Umstands gedachte. Einen Unterschied 
zwischen Elohim mit und ohne Artikel haben wir für B wohl nicht zu statuiren. Bei der Präposition steht das einfache אלהים in 3, 3 (אל־) und gemäfs der, allerdings לאלהים nicht ausnahmslosen, Gewohnheit der Punctatoren in 3, 3b (über באלהים 3, 5a s. nachher). Ohne Präposition

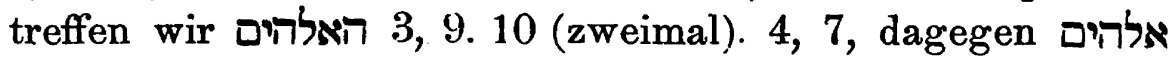
4, 9 und natürlich in ' 4,6 an. In Hinsicht auf 3, 8 und 4, 9 haben wir, denke ich, keinen Grund zu der Annahme, dafs $R$ in diesem untergeordneten Punkte die Schreibung seiner Quelle nicht bewahrt, oder dafs Jemand, nachdem er 4, 8 a eingefügt resp. vorgefunden, ein folgendes האלה 4, 4, 9 absichtlich geändert oder verschrieben habe. Ein einziges אלהים begegnet uns statt des erwarteten יהוה in einer aus A recipirten Stelle, nämlich 3,5 a. Da ich es als fraglich hingestellt habe, ob $\mathrm{B}$ eine Parallele zu 3, 5 enthielt, so vermuthe ich, dafs der Redactor, der ja eben in 3, 3b לאלהים nach $B$ gesetzt und sicherlich um der Verbindung seiner beiden Vorlagen willen den Abschnitt 3, 6 ff. noch einmal durchgelesen hatte, unter dem Einflufs von B unwillkürlich באלהים für das ביהוה von A schrieb. Doch will ich auch der Hypothese nicht entgegentreten, dafs er in diesem Capitel von $3,3 \mathrm{~b}$ an, wo er $\mathrm{B}$ zuerst vornahm, eine einheitliche Bezeichnung Gottes für erwünscht hielt und den Gottesnamen seiner Hauptquelle für Cap. 3, B, durchweg einsetzte, oder dafs er im Verkehr Gottes und Jonas mit den Heiden das allgemeinere Elohim für allein passend erachtete. Nur ist daran festzuhalten, dafs A hier wie in der ganzen Schrift Jahve, B hier und auch in Cap. 4 überall Elohim brauchte. - Das Lied 3, 3-5. 8. 10 weist an allen Stellen (V. 3. 8. 10) den heiligsten Namen auf. Darum können wir, nachdem wir bereits oben die Abfassung und Einschiebung desselben dem nüchternen, fast überall auf das Nothwendigste sich beschränkenden Darsteller $A$ abgesprochen, weder das eine noch das andere $B$ zuschreiben, der nach 
3, 10 gewifs auch in der Einführung desselben 2, 2 sich nicht des Ausdrucks יהוה bedient hätte. In dem Zusatz 2, 6 f. lesen wir יהוה אלהַי, dessen Aehnlichkeit mit 'יה אלהיו $2 \mathrm{~b}$ uns schon einmal auffiel. Da nun die Wendung aufser in 2, 2 a nur noch 4, 2 in unserm Buche auftritt (obwohl es zu ihrer sonstigen Anwendung nicht an Gelegenheit fehlte) und letztere Stelle unzweifelhaft zu C gehört, der sich in '1, 14, vgl. auch 1, 6 , vielleicht nach B oder nach der gewöhnlichen Redeweise richtete ${ }^{1}$ ), so läfst sich mit ziemlicher Sicherheit grade dem Ergänzer, bei welchem wir אלהיך vom Gott des Jona auch 1, 6b antreffen, sowohl die Einsetzung des Liedes mit den dasselbe einleitenden Worten 2, 2 nebst 2,3 als auch die Einschiebung der Verse $6 \mathrm{f}$. in das Gedicht zuweisen. Zur Unterstützung meiner Ansicht diene noch Folgendes. Die Phrase

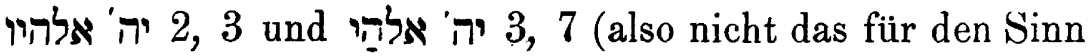
ausreichende אלהלה , אלהית), durch welche Jona trotz seines Ungehorsams noch als innig mit Jahve verbunden dargestellt wird (vgl. dagegen z. B. 1 Sam. 30,6) stimmt überein mit dem Bestreben von C, das Vergehen des Propheten in milderem Lichte erscheinen zu lassen (4, 2, auch 1, 14); daher die Uebertragung des Liedes, dessen Autor von keiner Schuld weifs, als einer Dankesäufserung für die Rettung auf den Jona, daher selbst in dem Einsatz $6 \mathrm{f}$. keine Erwähnung seiner Sünde. (Mit der Einfügung des Liedes hinter 2, 1 greift der Schriftsteller ebenso vor wie mit der Aeufserung 4, 3.) Sodann ist es recht wohl denkbar, dafs der gelehrte, der Sprache mächtige, mit Frische und Lebhaftigkeit schreibende Darsteller, wie wir C aus

1) Bei A steht in gleicher Bedeutung py 1,5 (übrigens ist Pỹ? statt Nרק: 1, 6 b nicht recht gebräuchlich und nur Ezech. 21, 17 vorhanden) und קר als predigen ${ }^{*}$ 1, 2.3, 2.4 b und (ein Fasten) ausrufen ${ }^{*} 3,5$. 
der Bearbeitang des Buches kennen, ein Freund, wie der Prophetie, so auch der Poesie war und als solcher sich, vielleicht unter Benutzung uns unbekannter Dichter in 2, $6 \mathrm{f}$. selbst poetisch versuchte; man lese Hitzig's Citate zu 1, 14b und 2, 6 f. Demnach erkenne ich in הקגה 2, 2 b (statt הקי A) den Schreiber des ebenfalls singulären 1, 5 b. - Abgesehen von den besprochenen Stellen finden wir אלהים noch in 4, $8 \mathrm{a}$, einem Halbvers, den wir oben, weil er das Vorhandensein der von Jona nach B erbauten, diesem Schriftsteller also wichtigen Hütte ignorirte, für $B$ nicht in Anspruch nehmen wollten. Sprachliche Differenzen, zu denen sich jetzt noch Elohim gesellt, trennen ihn von A, der gleiche Gottesname und die unfreundliche Gesinnung gegen den Propheten, die sich in dieser Interpolation offenbart, scheiden ihn auch von $\mathrm{C}$. Weist 4, 8 a auf 2, ה התעשף aurück, so ist er jünger als C, und sollte er in 4, 8 den Namen Elohim nur wegen der Nähe von 4, 7. 9 gebraucht haben, so dürfte nichts hindern, den störenden Vers 4, 4 trotz ${ } J_{a h v e}$ " von ihm herzuleiten, da in 4, 2 dieser Eigenname (zweimal) begegnet und ein Wechsel der Gottesbezeichnungen in derselben Verhandlung nicht räthlich erscheinen konnte.

Erst jetzt haben wir einen Ueberblick über den Antheil gewonnen, den $\mathrm{A}$, besonders aber $\mathrm{B}$ und $\mathrm{C}$, an unserm Büchlein haben. Noch bedarf es der Feststellung mehrerer nicht unbedeutender Punkte betreffend das Verhältnifs von $A$ zu $B$, von $C$ zu beiden, von $R$ zu allen, um die Aufgabe der Quellenscheidung, soweit das in unsern Kräften steht, zu lösen. Die Gleichheit der Sprache in denjenigen Partieen aller vier Capitel, welche ihre Herkunft von der ersten Relation nicht verleugnen können, sowie die Erwägang, dafs Jahve das Leben des Propheten zu einem bestimmten $\mathrm{Z}$ wecke erhalten haben mufs, lehrt uns, dafs A nicht hinter 2, 11 aufhörte, sondern dafs es eine Schrift aus einem Grusse war. Inhalt und Ausdrucks- 
weise derselben gab, wie in Cap. 1 und 2 dem C, so in 3 und 4 dem $B$ vielfach so wenig Anstols, dafs letzterer den Text von A einfach herübernehmen, höchstens in Kleinigkeiten ihn abzuändern für nöthig balten konnte, z. B. in 4, 8 b. 9. Eine gemeinsame Grundlage, die wir uns A sehr ähnlich vorstellen müfsten, ist also, wie oben bemerkt, für beide Autoren in den Capiteln nicht anzunehmen. Zurückbeziehungen auf den Inhalt von Cap. 1 und 2 fehlen in 3 und 4 in A aufser שית 3,1; sie waren für A nicht erforderlich, doch hätte ein gewandterer Erzähler dieselben. in den Reden des Jona oder Jahve oder auch sonst gewifs nicht unterlassen. In $\mathrm{B}$ war dergleichen von vornherein unmöglich; eifrig dagegen greift C 4, 2 auf 1, 3 zurück, um auf Grund des ihm aus Joel bekannten Verhaltens Jahves den Propheten von einem beschimpfenden Vorwurf wegen seines eigenen früheren Verhaltens zu befreien. Weshalb die erste Hälfte des Berichts von $\mathrm{A}$ über Jona durch B nicht reproducirt wurde, darüber lassen sich nur Vermuthungen hegen. Vielleicht erhielt die Erzählung von einer directen Uebertretung des göttlichen Gebots durch einen von Gott mit Offenbarungen begnadeten und als Jahves Diener auch 2 Kön. 14, $2 う$ bezeichneten Propheten nicht den Beifall von B; vielleicht beabsichtigte er auch nur, seinen Zeitgenossen oder seiner Umgebung im Besondern an einem eclatanten Beispiel zu zeigen, dafs Gott bei einer gründlichen Sinnesumwandlung, zu der sich Hoch und Niedrig, Mensch und Thier, eine ganze Stadt oder ein ganzes Land entschliefse, zur Milde und Vergebung bereit sei, selbst wenn er bereits die Vernichtung der Frevler angedroht habe. Die Unzufriedenheit von B mit der Art, in welcher innerhalb seiner Kreise oder auch anderswo Fasten gehalten und Bufse geübt wurde, mag ihn, da er sich hiervon keinen Erfolg bei Gott versprach oder gesehen hatte, zu einer eingehenden Beschreibung des Thuns der Nineviten bewogen haben, an 
dem sich seine Landsleute ein Muster nehmen sollten. Er verlangt nicht nur vollen Ernst in den Veranstaltungen zur Bufse, sondern auch die Betheiligung der Häupter des Volkes, vielleicht gar ein vorbildliches Vorangehen derselben ${ }^{1}$ ). Offenbar genügte ihm für seinen $\mathrm{Zweck}$ eine Umgestaltung von Cap. $3 \mathrm{f}$., die ihm um so leichter ward, als der zweite Theil des Jona auf den ersten aufser in שנית 3, 1 keinen Bezug nahm. An Umfang blieb seine Schrift, die wohl eine Zeit lang getrennt von A verbreitet wurde, hinter der von A kaum um den vierten Theil zurück.

Die Zusätze des mit $\mathbf{A}$ und $B$ vertrauten $C$ sind nur an denjenigen Stellen wahrzunehmen, wo entweder $\mathbf{A}$ allein existirte (Cap. 1 und 2) oder (4, 2) der dem Einschub von C voraufgehende Text die Fassung von A repräsentirt. Es wäre aber ein Irrthum daraus zu folgern, dafs B von C noch als selbständige Quelle vorgefunden, als solche von ihm gelassen und nur zur Ergänzung von A verwandt wurde; die von $A$ verschiedenen Abschnitte aus $B$ (und zu denen kann man z. B. 4, 1 inhaltlich nicht rechnen) boten ihm nur keine Veranlassung zur Erweiterung und Ausschmückung. Was hätte er auch zu der Rede in 4, $10 \mathrm{f}$. oder 3, $7 \mathrm{ff}$., welche letztere ja ihm Gelegenheit zu dem Einsatz 4, 2 f. gegeben hat, Wichtiges hinzufügen sollen? Meines Erachtens las $\mathbf{C}$ bereits das von $\mathbf{R}$ geschaffene Buch AB, ohne von dessen Entstehung noch Kunde zu besitzen und die einzelnen Bestandtheile desselben nach ihren Quellen scheiden zu können. Von einem Schriftsteller, der consequent יהוה sagt und der sich auch durch den häufigen Gebrauch von אלהים in B (Cap. 3) nicht bestimmen läfst, sich in Cap. 4,2 f. einmal zur Abwechselung

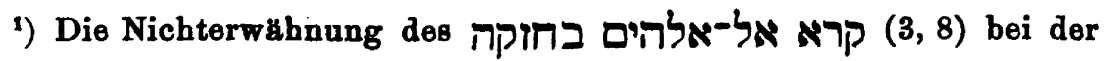
Schilderung des Thuns des Königs 3, 6 ist wohl ein Beweis, dafs B anfangs von $A(3,5)$ abhkngig schrieb. 
dieses Gottesnamens zu bedienen, ist schwerlich anzunehmen, dafs er aus irgend welchem Grunde jenes באלהים 3, כ geschrieben habe, wo in A ביהוה stand. Ebenso steht mit der zwanglosen Weise, mit welcher er den Text (von A) behandelt, und mit dem freien Tone, mit welchem er seine Personen, selbst gegen Jahve, auftreten lärst, die ängstliche Rücksicht auf das (von ihm selbst nie gesetzte) אלהים von $B$ in יהוה אלהים 4, 6, sowie das Schwanken zwischen Elohim und Jahve (4, 8 vgl. mit V. 9), sogar innerhalb derselben Verhandlung, durchaus nicht im Einklang. Bei der Ansicht, dafs $\mathrm{R}$ später als $\mathrm{C}$ lebte und $\mathrm{AC}$ mit $\mathrm{B}$ vereinigte, vermögen wir auch auf die Frage keine befriedigende Antwort zu geben, weshalb $\mathrm{C}$ nicht selbst der geringen Mühe sich unterzog, die mit seinen Anschauungen wohl verträgliche kleine Schrift $B$, die doch so vielfach mit A zusammenging, wenn auch mit unbedeutenden Aenderungen wie etwa der des Gottesnamens an einigen Orten, mit dem nicht viel grölseren A zu verbinden; hat er doch nach unserer Meinung das Lied 2, $3 \mathrm{ff}$. dem ganzen Werke einverleibt. (Dafs $\mathrm{C}$ von $\mathrm{R}$ oder $\mathrm{R}$ von $\mathrm{C}$ gekannt wurde, ist an sich eben so wenig zu erweisen als zu widerlegen.)

Ueber $R$, den wir uns also von $C$ verschieden und zwar älter als den Ergänzer denken, ist hier noch Einiges nachzutragen. Gleich A, B und C hat auch er Fehler begangen. Dieselben entspringen wahrscheinlich dem Umstand, dafs er dem Gange seiner Hauptvorlage A auch da folgt, wo ihm die Abweichungen in B eine andere Anordnung der Begebenheiten hätten anrathen sollen. In A fand er u. a. 3, 5. 10 (nach seinem Inhalt) 4, 1. 5 a (wie vorher) 6 u. s. w., in B 3, 6-9. 4, 5. 3, 10. 4, 1 (mindestens inhaltlich) u. s. w. Um B willen hätte er nun 3, 6-9 vor 3,5 (worin dann einiges abzuändern war), 4, 5 vor 3,10 stellen müssen. Indem er aber hinter 3, 4 noch bei A verweilte ${ }^{1}$ ) und in 3, 10 sowie in 4,5 die Darstellung

1) Die Verschiedenheit hinsichtlich der Angaben von A 3, 5 und 
von $\mathbf{B}$ wiedergab, weil $\mathbf{A}$ an den betreffenden Stellen von der Rene Gottes resp. der Entfernung des Jona aus der Stadt erzählte, hat er eine schlimme Verwirrung angerichtet. Tritt man dieser unsrer Meinung bei, so braucht man nicht für $\mathrm{B}$ die Aufeinanderfolge von 3, 6-9. 10. 4, 5, dahinter aber den Ausfall eines Verses anzunehmen, der etwa Fol-

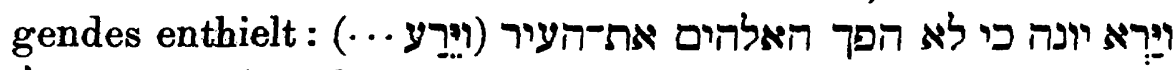
לו קו diese Stelle. Vielmehr trifft die Schuld nur R, der nicht begriff, dafs das seinen Quellen gemeinsame וּיָ in einer jeden zu andrer Zeit vor sich ging. Vielleicht pflegte der bei der Aufnahme der Gottesnamen aus seinen Quellen so schwankende (3,5 באלהים schreibende) Redactor im eigenen täglichen Gebrauch das heilige Jahve zu vermeiden, eine Gewohnheit, durch die er sich von $C$ aufs deutlichste unterscheiden würde. Zusätze von ihm sind nirgends zu entdecken; ist der ein Elohim enthaltende Halbvers 4, 8 a nicht ohne Erinnerung an 2, 8 geschrieben, so kann er mit $R$, dem Vorgänger von $C$, welcher letztere vermuthlich 2, $3 \mathrm{ff}$. erst in unser Buch einführte, nichts zu thun haben.

Auch nach $\mathbf{R}$ und $\mathbf{C}$ hat die Beschäftigung mit dieser Schrift nicht aufgehört, welche, einen populären Stoff in populärer Weise behandelnd, sicherlich bald nach ihrem Erscheinen einen ausgebreiteten Leserkreis fand. Wie in 4, $8 \mathrm{a}$, so erblicken wir auch in 4,6 להציל וג, 4, 4, in 3, 7,

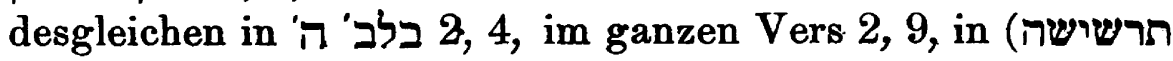
1,12 Interpolationen, die von regem Interesse für die Erzählung zeugen und vielleicht von mehreren Verfassern ausge-

B 3, 6 ff. mag er sich so zurechtgelegt haben, dafs die Verfügung des Königs erging, weil derselbe die Bufsübungen seiner Unterthanen als anzureichend mifsbilligte; dann mufste natürlich 3,5 vor 3,6 stehn. 
gangen sind. Mit Ausnahme von 1, 8 לאשו bis alle Einschiebungen bereits von der LXX vorgefunden worden.

Für die Bestimmung der Entstehungszeit des B. Jona giebt die Beziehung auf dasselbe (wahrscheinlich auf das ganze) in Tob. 14, 4 keinen Anbalt, da wir nicht wissen, wann letzteres Buch (nach Schürer in Herzogs RE. „etwa im Laufe der letzten zwei Jahrhunderte vor ('hristo") verfafst ist. Von Nöldek e die alttest. Liter. S. 80) wird Sir. 49, 10 zum Beweise dafür verwandt, dafs man das Alter unserer Schrift nicht zu tief herabsetzen dürfe.

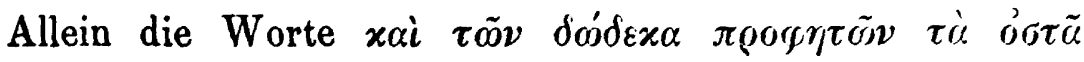

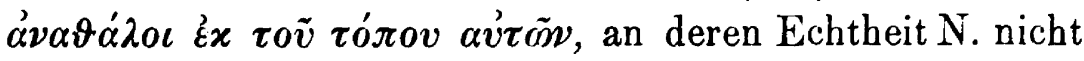
zweifelt, sind eine Einfügung in den Text, welche das Lob des Ezechiel (V. $9 \dot{\varepsilon}^{\prime} \mu \nu \eta^{\prime} \sigma \vartheta \eta-$ V. $10 \pi \mu \rho \varepsilon x \dot{c}^{\prime} \lambda \varepsilon \sigma \varepsilon-$

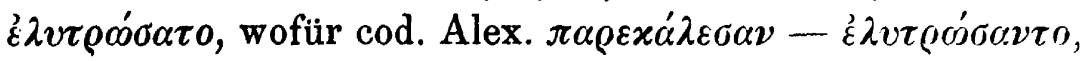
offenbar eine Correctur) unterbricht, und rühren von Jemand her, der es unrecht fand, dafs der kleinen Propheten nicht gedacht wurde. Jener Wunschsatz, der von der geschichtlichen Darstellung in seiner Umgebung absticht, ist

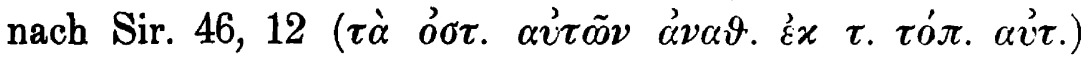
formulirt.

Somit stände der Vermuthung, dafs das Buch Jona in der uns vorliegenden Gestalt in den letzten Jahrhunderten vor Chr. entstanden sein möchte, von Seiten der äufseren Zeugnisse für die Existenz desselben nichts im Wege. Es fragt sich nur, ob die bei vielen Kritikern geltende, ${ }^{\text {wis- }}$ senschaftlich allein zu rechtfertigende Annahme einer nachexilischen Abfassung" (d e W et t e-S ch rader in der Einleitung in das A. T.) auch jetzt noch festzubalten ist, wo wir den Ursprung des Buches aus verschiedenen Quellen nachgewiesen zu haben glauben. Da mich nun eine Behandlung des Inhalts und der Anlage der für alle Nachfolger in der Hauptsache mafsgebenden Schrift A, auf die es daher vorzugsweise ankäme, hier zu weit führen würde, so erlaube ich mir nur noch einige sprachliche Beobach- 
tungen mitzutheilen, die, theilweise in Uebereinstimmung mit den bisher gemachten, geeignet sind, die obige Annahme einer ziemlich spät nachexilischen Entstehung schon des Originals für das Buch Jona zu bestätigen.

In A will ich auf הלך Statt בוא Jon. 1, 3 (Hitzig, unter Vergleichung von $2 \mathrm{Chr}$. 9, $21 \mathrm{~b}$ und $1 \mathrm{Kön} .22,49$ ) kein Gewicht legen, auch nicht auf עם ebendaselbst, welches nach demselben „besonders bei Späteren (1 Chr. 15, 18. 2 Chr. 20, 1. Esr. 10, 14) steht." Das Verbum סער vom Meer 1, $11 \mathrm{mag}$, wie dies ja von חתר 1, 13 möglich ist, der Schiffersprache entnommen und (יהוה) 1, 9 (de Wette), eine Wendung, die schon in Gen. 24, 7 (dort ächt? vgl. V. 3) vorkommt, in den hebräischen Sprachgebrauch nicht erst mit der Zeit des Nehemia (aufser diesem vgl. Esr. 1, 2. 2 Chr. 36, 23 und die aram. Zusätze in Esr. und Dan.) eingedrungen sein. Bedenklicher ist שת, abgesehen von Jon. 1, 12 nur noch (vom Meer) Ps. 107, 30 und (vom Streit) Spr. 26, 20, und הom Senden (nicht Werfen) Jon. 1, 4, sowie ๆ Iַ "Zorn, Zürnen“, von einem leblosen Gegenstande 1, 15 gesagt. An Stelle von וישאו . וישל ebendas. würde man erwarten. Stärkere Abweichungen vom älteren Hebräisch sind die noch zu erwähnenden. Bei מלפני מוס unden wir sonst häufig מפני ברח bei נום nur $1 \mathrm{Chr}$. 19, 18 in der Parallele zu 2 Sam. 10, 18 (woselbst מפני) und bei ברח Jon. 1, 3 (bei C 1, 10). Der abgeschwächte Gebrauch von חשר 1, 4 nahe daran sein", nicht sehr verschieden von היח (wie im Französischen il a pensé mourir), hier noch dazu mit einer Sache als Subject, sodann ירָ vom Religionsbekenntnifs 1, 9 weisen auf eine fortgeschrittene Zeit. Die Construction 4, 1

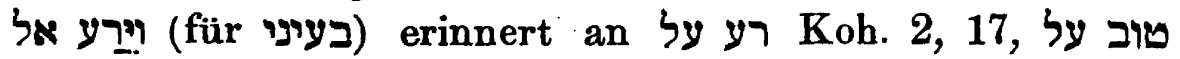
Neh. Esth. (Esr. 5, 17 aram.); אל steht für לy in 4, 1, wie beide Präpositionen Jon. 3, 2 vgl. mit 1, 2 wechseln; nur Nehem. schreibt 13, וירע להם und 2, וירע לי מאד 
.רעה גרולה Das in der Bedeutung, ,bestellen" selbst in der Chronik (I, 9, 29) nur einmal, also vermuthlich in einer Interpolation angetroffene מָּ (de W.), welches in gleichem Sinn nur noch Dan. 1, 11 bietet (Ps. 61, 8 ist corrumpirt), wird in A mehrfach von Gott ausgesagt. - Eine Schrift, die von einem Propheten handelt, ihn mit Jahve reden und weissagen lälst, sollte, wenn sie zur Zeit der Prophetie in Israel verfafst wurde (nach Volck in Herzogs RE. „geraume Zeit vor der Zerstörung des nördlichen Reiches!"), mindestens einige Phrasen aus dem prophetischen Sprachschatz enthalten wie שמעו ,כה אמר יהוה דבר יה u. a. Im B. Jona aber befremdet nicht allein die Abwesenheit solcher Wendungen, nein, es fehlt sogar גביא, נפטא und u. s. w. Des Propheten Thätigkeit wird ein קרא, wozu man schon Jes. 40, 6 verglichen hat, seine Rede mit einer im jüngern Hebraismus beliebten, früher seltenen Wortbildung קריאה genannt. Nach Einigen soll sich die Herkunft des Buches aus Nordisrael aus dem präfigirten $(1,7.12)$ ergeben; aber so lange wir genauerer Daten über Ort und Zeit der Entstehung sowie über die Art der Verbreitung jener aus אשר abgekürzten Partikel entbehren, können wir das Vorhandensein derselben als Argument nicht verwenden. Nicht undenkbar ist, dafs auf unsere Schrift Ps. 139, 7 eingewirkt hat, dieser Umstand würde sie, da der genannte Psalm an Aramaismen überaus reich ist, ziemlich weit herabrücken.

Für B ist ein Ausdruck charakteristisch, in welchem כף verbunden auftritt, 3, 8, wie Hiob 16, 17. Jes. 59, 6. 1 Chr. 12, 17. Dazu kommt מהלך 3, 3 f. für ריפ (1 Kön. 19, 4), vgl. (Ezech. 42, 4) Neh. 2, 6;

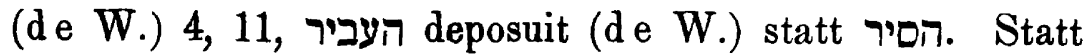

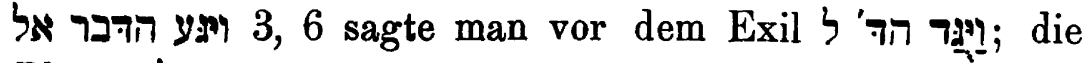
Phrase נגר אל אל lesen wir noch Dan. 9, 21, wie überhaupt 
נגע im Sinne von מצט , בוא später sehr verbreitet. Schon wegen der Berücksichtigung von Joel 2, 14 in Jona 3, 9 darf man, da Joel ,um 500 resp. später" (M er $\mathbf{x}$ ) geschrieben ist, mit B nicht in die Zeit des Bestehens der Reiche Israel oder Juda hinaufgehen.

Die mannigfachen Anklänge im Liede Cap. 2 an frühere Dichtungen, besonders an Jes. 38, 11 und die Psalmen (18.) 142, 4 (Jon. 2, 8). 31. 42, auch 88 (zu V. 5. 7. 8 vgl. Jon. 2, 8. 4), verrathen einen Compilator, dessen poetisches Verdienst äufserst gering ist, doch läfst sich nicht mehr ermitteln, ob das Lied schon vor $A$ und $B$, oder erst einige Zeit vor $\mathrm{C}$ gedichtet wurde.

$\mathrm{C}$ giebt Proben von einer ähnlichen Belesenheit wie der Urheber des Gedichtes, sowohl in der Erweiterung desselben (nach Jes. 38 und Psalmen; עד נפש aufser Jon. 2, 6 nur Ps. 69, 2) wie in seinen übrigen Zuthaten zum Buche. 4, 2 citirt er gar einen längeren Halbvers des Joel, wobei man beachte, dafs er die Anspielung auf den unmittelbar vorhergehenden Vers dieses Propheten in B Jon. 3, 9 sofort erkannt hat. Der Gebrauch von

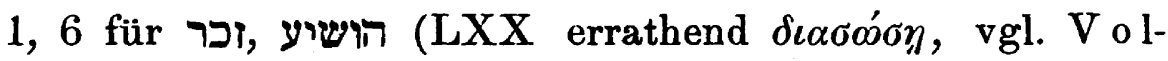
lers), von אפינה, (Schrader) für und wahrschein-

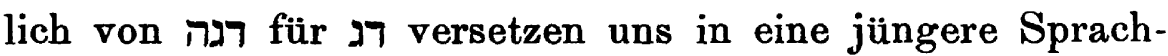
epoche; die Orthographie נקיא, welche er mit Joel 4, 11 theilt ${ }^{1}$ ), und אפה beweisen, dafs selbst dieser Gelehrte kein Interesse mehr an der richtigen Schreibung von Wörtern hat, deren ursprüngliche Gestalt sich das Volk sicherlich nicht zu erklären wufste.

1) Ich bemerke übrigens, dals ich Joel 4, 18-21 für eine spätere Anfügung ansehe; schon 4, 17 schliefst die Prophetie passend ab, und nur eine lästige Wiederholung der Verlegenheit ist יזוה ששכין בצין V. 21 nach V. 17. Ebenso ist 2, 18-21 auszuscheiden, desgleichen 1, 4, ein Vers, der mit seiner vielbesprochenen Deutung der Allegorie 1,6 unziemlich vorgreift, und vermuthlich noch manches Andere. 


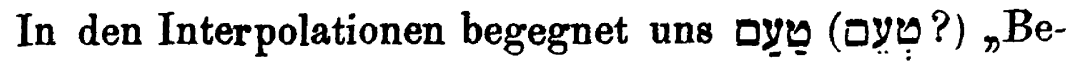
fehl ${ }^{\star}$ Jon. 2, 7 als aramäisches Wort, ๆ 38, 14 sich verhüllen“) nach Am. 8, 13, 4ציל 4, 6 (Sch rader); שוא 2, pleonastisch, ist direct aus Ps. 31, 7 entlehnt.

Wie weit A, B, R, C und die Zusätze zum Buch zeitlich auseinanderliegen, läfst sich nicht abschätzen. Erwägen wir nun, 1) dafs A sich der nachexilischen Redeweise bedient, 2) dals die Abänderungen von A wie von den älteren Texten überhaupt nur in einem geraumen Zeitabstande unter einander vorgenommen sein können, 3) dals die LXX alle Erweiterungen (aufser dem Sätzchen in 1, 8) bereits kennt, so werden wir wohl berechtigt sein, die Abfassung der Grundschrift in das vierte oder dritte (kaum das zweite) vorchristliche Jahrhundert zu verlegen.

Am Schlufs gestatte ich mir noch einmal kurz diejenigen Schriftsteller namhaft zu machen, welche nach meiner Auseinandersetzung am Buche Jona betheiligt gewesen sind, nämlich :

1) A, der Verfasser des Kerns von Cap. 1-4 (Jahvist);

2) B, der Autor einer mit dem zweiten Theil von A parallelen, mehrfach differirenden Erzählung in Cap. 3 und 4 (Elohist);

3) $R$, der Vereiniger von A und B (vermuthlich Elohist);

4) C, der Erweiterer von ABR in Cap. 1 und 4, und zugleich der Ergänzer und Einfüger des von einem unbekannten jüngeren Dichter herrührenden Liedes in Cap. 2 (Jahvist);

5) der oder die Urheber kleinerer Einsätze in allen Capiteln, am spätesten der Glossator in $1,8 \mathrm{a}$ (nach der LXX). 